Alexander E. Kentikelenis

University of Oxford

Thomas H. Stubbs

University of Cambridge

Lawrence P. King

University of Cambridge

\title{
IMF conditionality and development policy space, 1985-2014
}

\begin{abstract}
$\underline{\text { Abstract }}$
In recent years, the International Monetary Fund (IMF) has re-emerged as a central actor in global economic governance. Its rhetoric and policies suggest that the organization has radically changed the ways in which it offers financial assistance to countries in economic trouble. We revisit two long-standing controversies: Has the policy content of IMF programmes evolved to allow for more policy space? Do these programmes now allow for the protection of labour and social policies? We collected relevant archival material on the IMF's lending operations and identified all policy conditionality in IMF loan agreements between 1985 and 2014, extracting 55,465 individual conditions across 131 countries in total. We find little evidence of a fundamental transformation of IMF conditionality. The organization's post2008 programmes re-incorporated many of the mandated reforms that the organization claims to no longer advocate and the number of conditions has been increasing. We also find that policies introduced to ameliorate the social consequences of IMF macroeconomic advice have been inadequately incorporated into programme design. Drawing on this evidence, we argue that multiple layers of rhetoric and ceremonial reforms have been designed to obscure the actual practice of adjustment programmes, revealing an escalating commitment to hypocrisy.
\end{abstract}

\section{Acknowledgments}

We thank Peter Bakvis, Nathan Coplin, Jo Marie Griesgraber, David Lane, Matthew Martin, Sargon Nissan, Isabel Ortiz and three anonymous reviewers for helpful comments, and Joshua Watts for excellent research assistance; the usual disclaimers apply.

\section{Funding}

The authors gratefully acknowledge funding by the Institute for New Economic Thinking (INET Grant INO13-00020: 'The Political Economy of Structural Adjustment'), the Cambridge Political Economy Society Trust, and the Centre for Business Research at the University of Cambridge. 
'Structural adjustments? That was before my time. I have no idea what it is. We don't do that any more. No, seriously, you have to realise that we have changed the way in which we offer our financial support.'

— Christine Lagarde, IMF Managing Director (IMF 2014g).

'Having known the history of [IMF] programmes, [...in Iceland] the IMF was really rather flexible. I can't really make sense of this new, cuddly IMF; it can't possibly last.'

- Martin Wolf, Financial Times chief economics commentator (Wolf 2011).

\section{$\underline{\text { Introduction }}$}

The International Monetary Fund (IMF) has had a tumultuous past decade. In the mid-2000s, demand for its services was at historic lows, resulting in staff layoffs and widespread doubts about its future (Momani and Helleiner 2007). Noting this demise, anthropologist and activist David Graeber (2008:16) pronounced that 'the IMF is rapidly approaching bankruptcy, and it is a direct result of the worldwide mobilization against them. To put the matter bluntly: we destroyed it.' Critics in academia and civil society, as well as anti-IMF protestors around the world, could feel vindicated. Yet, such celebrations proved premature. In the face of the ongoing global financial crisis, G-20 leaders committed \$750billion in 2009 to enable the IMF to step up its operations (IMF 2009a:10). Reflecting the significance of this cash injection, its Managing Director at the time, Dominique Strauss-Kahn, could safely proclaim that 'the IMF is back' (BBC 2009). Between 2009 and 2014, the organization made 129 new loans to 76 countries, reinforcing its standing as the central actor in global economic governance and crisis management.

Yet, the IMF's recent revival has been accompanied by an unfamiliar discourse. As the opening quote by current Managing Director Christine Lagarde suggests, 'we don't do that any more' has become a mantra of the organization. This tone is far removed from what observers have long come to expect from the IMF, and is a clear departure from the reputation that normally precedes it, namely prescriptions of fiscal austerity, trade and capital account liberalization, public sector layoffs, and 'structural reforms' (Babb and Buira 2005; Chang 2006; Stiglitz 2002). Instead, the organization now acknowledges the importance of countercyclical spending to sustain economic activity (Berg et al. 2009; IMF 2009c), the potential utility of capital controls (IMF 2010b; 2011a; Ostry et al. 2010), the possible perils of high 
income inequality (IMF 2014c), and the adverse consequences of inadequate social protection policies (IMF 2014f; 2014b; 2015b). ${ }^{1}$

Taken at face value, such policy advice would indeed amount to a monumental shift in the organization's practices. Some scholars have identified the potential onset of an organizational recalibration in these developments (Ban 2015; Ban and Gallagher 2015; Broome 2014; Grabel 2011). Even so, there remains reason for scepticism as some studies suggest that the practice of IMF programmes in recent years largely reflects business-as-usual (Gabor 2010; Grabel 2011; Griffiths and Todoulos 2014; Güven 2012; Muchhala 2011; Van Waeyenberge, Bargawi, and McKinley 2010; Weisbrot et al. 2009). For example, Weisbrot and colleagues (2009) revealed that 31 of the 41 recent IMF loans they examined contained pro-cyclical macroeconomic policies. Similarly, Griffiths and Todoulos (2014:4) pointed to 'widespread and increasing use of controversial conditions in politically sensitive economic policy areas.' The IMF has challenged the accuracy and veracity of such conclusions (e.g. Reuters 2014; Roaf 2009). Until now, however, short timeframes and small samples have limited our ability to evaluate these competing claims.

This paper examines the evolution of IMF-mandated policy reforms-so-called conditionality - and assesses whether the recent rhetoric of the organization has translated into actual policy practice. We focus on two long-standing controversies: Has the policy content of IMF programmes changed to allow for more policy space? Do these programmes now factor in considerations over their consequences on labour and social protection policies? To explore these issues, we collected relevant archival material on the IMF's lending operations and identified all policy conditionality in IMF loan agreements between 1985 and 2014. In total, we retrieved over 4,500 loan-related documents, from which we extracted 55,465 individual conditions applicable across 131 countries. We focus exclusively on the content of IMFmandated reforms, setting aside the questions surrounding the extent to which IMF conditionalities are owned by—rather than imposed upon—-borrowing countries.

We find little support for the 'fundamental transformation' thesis. Although in the immediate aftermath of the global financial crisis the scope of reforms covered in IMF lending programmes was somewhat reduced, what appeared at the time as a period 'pregnant with new development possibilities' (Grabel 2011:805) never came to fruition. Instead, as the IMF solidified its role as the central institution charged with crisis management and built up organizational self-confidence anew, its programmes re-incorporated many of the reforms that it claimed to no longer advocate. The most recent data from 2014 show a sharp increase both in the total number of conditions and in the array of policy areas under reform.

\footnotetext{
${ }^{1}$ In addition, the organization's Research Department has also published new research as 'Staff Discussion Notes' (Dabla-Norris et al. 2013; 2015; Ostry, Berg, and Tsangarides 2014) that often go beyond official IMF line, as expressed in press releases, policy statements, or factsheets. The extent to which these findings are taken up in programme design is unclear, but recently, the IMF's own Independent Evaluation Office (IEO 2011 p. vii) reported 'a widespread view among IMF staff' that research findings were misaligned with the organization's policies. These issues are not further explored here.
} 
What explains the apparent distance between the IMF's rhetoric-broadcasted in the organization's Review of Conditionality (IMF 2012b), factsheets, press releases and responses to critics - and the actual practice of the policy reforms that the organization designs? We interpret our findings as evidence of the twin processes of 'paradigm maintenance' and 'organized hypocrisy' in international bureaucracies (Güven 2012; Lipson 2007; Wade 1996; Weaver 2008).

Extending this work, we argue that the production and maintenance of hypocrisy is a dynamic process that necessitates an intensification of efforts in order to maintain myths about organizational practices. We identify this process as escalating commitment to hypocrisy. For the case of the IMF, we show that as the organization invested in the maintenance of a myth about its actual practices, it also became more adept and inventive at obscuring reality. This occurred through the rebranding of existing practices and the addition of token gestures to placate critics, without altering the underlying premises of reform design. In short, we show how the maintenance of business-as-usual practices became tenable only by adding ever-more layers of ceremonial reforms and rhetoric.

The analysis proceeds as follows. First, we elaborate on and extend analytical approaches to the study of hypocrisy by international public bureaucracies. Second, we briefly discuss the origins of and debates around IMF conditionality. Third, using our original data, we present general trends in the application of conditionality over the past three decades. Subsequently, we weigh the evidence on recent IMF rhetoric versus practice in two policy areas: social protection and labour issues. We conclude by reconsidering how much policy space is available to developing countries under IMF programmes, and by discussing the implications of our findings for academic and policy debates.

\section{Escalating commitment to hypocrisy}

Contemporary organizations are best understood as 'open systems' influenced both by external environments and internal pressures and demands (Pfeffer and Salancik 1978; Scott 1995). As a result, a 'decoupling' can emerge between stated goals and actual practices of organizations (Meyer and Rowan 1977). Since evidence of this decoupling can threaten legitimacy and resources on which organizations are dependent (Powell and DiMaggio 1991), they attempt to mask this apparent disjuncture by engaging in 'organized hypocrisy' (Brunsson 1989; 1993), which is necessary for organizational survival: 'Without hypocrisy, one party or interest would be completely satisfied and all others completely dissatisfied. With hypocrisy, several parties and interests can be somewhat satisfied' (Brunsson 2003:206). In other words, to maintain their standing and relevance, organizations need to respond to pressures, but they may do so in a ceremonial—rather than substantive—manner (Meyer and Rowan 1977; Scott 1995).

These insights from organizational sociology have been introduced to the study of international public bureaucracies, which face a range of pressures from their principals (states), organizational environments, internal bureaucratic or technocratic agendas, andoccasionally - the public. Catering to contradictory demands would obfuscate bureaucratic action, therefore a degree of hypocrisy has come to be anticipated by students of these 
organizations (Bukovansky 2010; Lipson 2007; Mundy and Menashy 2014; Weaver 2008). These accounts have distinguished between different gradients of hypocrisy: from blatant violations of established policies, to greyer areas where rhetoric is inadequately, superficially or haphazardly translated into practice. Yet, despite the widespread practice of organized hypocrisy, intergovernmental organizations are highly sensitive to such accusations, insofar as these can erode their legitimacy (Seabrooke 2010). Two responses can be deployed to defend against such challenges. One path involves accepting criticism in a way that necessitates corrective action. ${ }^{2}$ Alternatively, organizations can opt to respond to accusations of hypocrisy by adding another layer of hypocrisy.

In this article, we examine the latter process, whereby maintaining myths about actual practices over extended periods of time necessitates intensification of efforts. We identify this layering process as escalating commitment to hypocrisy: rhetorical commitments are overlaid with a rebranding of activities, issuing factsheets showcasing a biased and/or inaccurate assessment, or instituting new policies that are never adequately incorporated into organizational practice. This path of action entails considerable 'sunk costs' and explains behaviour-persistence (Simon 1997), since backtracking after years (or decades) of ceremonial commitment to a goal can result in significant reputational damage and legitimation crises.

To support this argument, we revisit debates surrounding the practice of IMF conditionality. In particular, we examine the relationship between conditionality and development policy space. We understand policy space as a government's ability to select the policy instruments via which they address their economic problems, free from coercive conditionalities. Insofar as IMF adjustment programmes are indicators of underlying economic trouble, policy space is already expected to be somewhat limited. But even under constraining economic conditions, policy options remain. According to our understanding, then, governments with IMF programmes have greater policy space when they can choose exactly how to mend large external or budgetary imbalances; but less policy space when conditionalities specify the policy instruments by which they must address these imbalances (for instance, via increasing value added tax or privatising natural resources). ${ }^{3}$

\footnotetext{
${ }^{2}$ A recent World Health Organization (WHO) mishap is revealing of the reluctance of international organizations to follow this route. Responding criticisms over its role in the Ebola crisis, the organization issued an uncharacteristically strongly-worded statement: 'we did not work effectively in coordination with other partners, there were shortcomings in risk communications and there was confusion of roles and responsibilities' (The Guardian 2015). The initial reaction by observers was that 'by using strong and clear language the WHO's Leadership had decided to take a new approach to dealing with the criticisms' (Grepin 2015). This was not to last. Within hours, the WHO edited the passage into more circumspect language: 'We have learned the challenges of coordination. We have learnt to recognise the strengths of others, and the need to work in partnership when we do not have the capacity ourselves' (WHO 2015).

${ }^{3}$ Our understanding of development policy space applies to countries at all income levels that are under distress and IMF supervision, and is similar to that of other scholars in this field (Chang 2006; Cooper 1968; DiCaprio and Gallagher 2006; Gallagher 2010; Grabel 2011; Kumar and Gallagher 2007; Mayer 2008; Shadlen 2005; Wade 2003). Like these accounts, we acknowledge that open economies do not have absolute policy autonomy, as they need to respond to changes in the global economic
} 


\section{$\underline{\text { Recurring controversies on IMF conditionality }}$}

The IMF was founded at the Bretton Woods conference of 1944, and has since become the key intergovernmental organization underpinning the global financial system. Among its various activities (including data collection, research, and training policy elites), IMF lending programmes to countries in economic trouble have attracted most attention. In exchange for financial support, borrowing countries agree to implement a package of obligatory policy reforms (conditionality), phased over one or more years. In turn, the implementation of conditionality is assessed on a quarterly or bi-annual basis and determines the disbursement of IMF funds (in tranches). The content of conditionality has been among the most controversial outputs of any intergovernmental organization (Williamson 1983). Reviewing the full range of debates around these issues is beyond the scope of this article and available elsewhere (Babb and Carruthers 2008; Dreher 2009; Guitián 1995; Kapur 2005; Nelson 2014a; 2014b; Nowzad 1981; Spraos 1986; Vreeland 2003; Williamson 1983). Here, we revisit two persistent controversies: mission creep in the IMF's policy advice, and the social consequences of conditionality.

\section{(a) Mission creep}

The IMF's purpose, as stated in its Articles of Agreement, is to provide member-states 'with opportunity to correct maladjustments in their balance of payments without resorting to measures destructive of national or international prosperity. ${ }^{4}$ Excluding a short period after its establishment, the IMF has practiced conditional lending in pursuit of this objective. For the first four decades of its operations, conditionality included a set of predictable reforms that focused almost exclusively on budget deficit reductions, restrictive monetary policy, and exchange rate devaluations (Dell 1981; 1982; Diaz-Alejandro 1981; Williamson 1983); that is, areas understood to be covered by the IMF's mandate. At the same time, the IMF was mandated to remain neutral vis-à-vis its borrowers' economic and social objectives-an approach known as the 'doctrine of economic neutrality' (Finch 1983). For example, according to this approach, while the IMF provided support for a country's macroeconomic adjustment efforts, 'how the government brought down the deficit, by raising taxes or cutting expenditure, and the particular taxes or expenditure at issue [remained] the government's responsibility' (Polak 1991:39). In other words, IMF programmes did not make explicit attempts—at least via conditionality — to change the underlying structure of borrowing countries' economies.

However, in the 1980s, responding to political pressures and new economic ideas, the IMF's programmes expanded their policy content to include a range of 'structural' conditionalities,

environment. Consequently, the question is not whether or not these countries have to adapt, but the terms and conditions under which they do so.

${ }^{4}$ While the IMF's lending practices attract most attention and controversy, the organization also has other important functions - for instance, collecting and publishing data, conducting 'surveillance' of its members' economic policies or providing technical assistance. These aspects of IMF activities are not discussed here. 
moving well beyond what the IMF's founders had prescribed in the Articles of Agreement (Babb and Buira 2005). The era of so-called structural adjustment saw the involvement of the IMF in sensitive policy areas, such as the privatization of state-owned enterprises, trade and financial liberalization, and economic deregulation (Summers and Pritchett 1993; Toye 1994; Williamson 1990). Over subsequent years, the remit of conditionality expanded further to cover a growing array of policy areas, including social policy, labour market reforms, and 'good governance' (Babb 2013; Chang 2006; Rodrik 2002; Serra and Stiglitz 2008; Stiglitz 2002; Stubbs, Kentikelenis, and King 2016). Scholars understood the widening number of policy areas that IMF-prescribed policies covered-known as scope of conditionality - as 'mission creep' (Babb and Buira 2005). These arguments suggest that the IMF's conditionality moved beyond its core mandate of economic issues and 'into areas that properly belong in the realm of politics' (Stiglitz 2002:44-45), thereby challenging national sovereignty and domestic autonomy to design policy (Babb and Carruthers 2008; Krasner 1999; Przeworski and Vreeland 2000). In particular, after the organization's handling of the Asian financial crisis of the late 1990s, a growing chorus of academics and policymakers strongly criticised the organization for advocating reforms in many and disparate policy areas, frequently with little direct relevance to the IMF's core areas of expertise (Feldstein 1998; Goldstein 2001; Meltzer 2000; Radelet and Sachs 1998; Stiglitz 2002).

Following this torrent of high-profile criticisms, the IMF itself acknowledged the sprawling of conditionality in an excessive number of policy areas and embarked on a long process of 'streamlining' (IMF 2001). New lending programmes would, in the IMF's words, afford 'policy space' to governments as long as they reached 'the standard that members' policies must meet in order to qualify for Fund support' (IMF 2004). The IMF intended new principles underpinning the design of conditionality to mark a break from the past: 'ownership' of reforms, 'tailoring' to country specificities, 'parsimony' and 'clarity' in conditionality, and 'coordination' with other international organizations (IMF 2004). Yet, beyond rhetoric, the IMF's Independent Evaluation Office raised doubts about the extent of genuine change in lending operations, as conditionality remained 'very detailed, not obviously critical, and often felt to be intrusive' (IEO 2007b p. vii). ${ }^{5}$ Responding to the new round of criticisms, the IMF produced a series of self-congratulatory reports highlighting the apparent overhaul of past practices: 'programs are helping countries to weather the worst of the [global financial] crisis, [... and] program design [has] learned the lessons of the past' (IMF 2009h:43-44; 2009c). Indeed, 'flexibility' was the term touted in IMF reports to describe its policy advice in the early crisis period (IMF 2009e; 2009f; 2009b; 2009c; 2009h). Continuing on the same theme, in 2012, the organization's review of conditionality - the clearest articulation of the IMF staff's house view-concluded that 'program conditionality has generally been appropriately streamlined, even-handed, and tailored to country needs' (IMF 2012a; 2012b:4). In short, the

\footnotetext{
${ }^{5}$ The Independent Evaluation Office (IEO) was established in 2000, in part to counter persistent criticisms of the IMF's lack of transparency and accountability and to aid the organization's Executive Board in its oversight functions (Lissakers, Husain, and Woods 2006). The objective of this organization is to provide impartial assessments of IMF operations, and its reports scrutinize standard IMF practices and controversial cases. Given the high visibility and reputation of these reports, IMF staff commonly respond to issues raised in these reports.
} 
current IMF rhetoric conceives of its recent programmes as parsimonious and flexible, thereby definitively addressing past criticisms over its own mission creep and its undue restrictions on borrowing countries' policy space.

\section{(b) Social consequences}

Controversies surrounding the social consequences of IMF conditionality have a long history (e.g. Payer 1974). Critics argue that-by design or by omission-IMF conditionality can result in extensive 'collateral damage' in developing countries (Babb 2005). Furthermore, they argue that the social development policy agenda was never institutionalised within the organization (Vetterlein 2010). Reflecting these concerns, policy reforms designed by the IMF have recently been linked to increases in poverty and inequality (Garuda 2000; Oberdabernig 2013) and adverse health outcomes (Kentikelenis et al. 2011; Kentikelenis, Karanikolos, et al. 2014b; Rowden 2009; Stuckler and Basu 2009).

A strand of criticism prevalent in the early phases of IMF-designed adjustment programmes focused on the apparent blindness of the organization to issues beyond what was, at the time, a narrow macroeconomic agenda. A landmark study by UNICEF found that adjustment policies - such as rapid and/or excessive public expenditure reductions - could be linked to adverse effects on welfare and human development (Cornia, Jolly, and Stewart 1987). Similarly, referring to concerns over the social consequences of economic adjustment, the 1990 Human Development Report concluded that 'it is short-sighted to balance budgets by unbalancing the lives of the people' (UNDP 1990:34). Responding to such concerns, Jacques De Larosière, IMF Managing Director in the 1980s, acknowledged that 'adjustment that pays attention to the health, nutritional and educational requirements of the most vulnerable groups is going to protect the human condition better than adjustment that ignores them' (de Larosière 1986).

Despite this recognition by the IMF, criticisms of its policy advice only intensified. Trailing the expansion of the IMF's remit into an ever-growing number of policy areas, a new generation of studies furnished additional evidence of the links between IMF-designed reforms - like privatization, trade and financial liberalization, and the marketization of social policies - and adverse social consequences. Of the relevant debates (see Colclough and Manor 1991; Stewart 1991; Toye 1994; van der Hoeven and Stewart 1993), we revisit two issues that have attracted considerable attention.

First, the adverse effects of IMF conditionality on a range of labour-related indicators, including employment levels, wages and employment protection policies, have been welldocumented (Abouharb and Cingranelli 2007; R. G. Blanton, S. L. Blanton, and Peksen 2015; Garuda 2000; ITUC 2012; 2013; Lloyd and Weissman 2002; Marphatia et al. 2007; Rickard and Caraway 2014). For instance, Rickard and Caraway (2014) found that IMF borrowers reduce their spending on wages only when conditionality includes public sector reforms. Second, IMF conditionalities have been linked to a weakening of social protection policies, particularly on health (Kentikelenis, King, et al. 2014a; Rowden 2008; 2009; Stuckler et al. 2010). Recently, Stuckler and Basu (2009) examined whether IMF programmes affected the health systems of low-income countries, and found evidence linking the organization's policy advice to insufficient public health resources, unsuccessful health sector reforms, and impeded 
efforts in the combat against infectious disease and child and maternal mortality. Government wage bill ceilings have also been identified as a key impediment to hiring or retaining muchneeded health sector workers (Goldsborough 2007; Lefrançois 2010; Marphatia 2009; McColl 2008; McCoy et al. 2000; Rowden 2008).

The IMF has responded to these criticisms by claiming that its modus operandi now incorporates due attention to social protection issues. In relation to government wage bills, for instance, the IMF reports that they no longer rely on such policies (Fedelino, Schwartz, and Verhoeven 2006; Gupta 2015; Martijn and Tareq 2007; McDonald 2007; Verhoeven and Segura 2007). The organization has also repeatedly argued that recent lending programmes include conditions 'designed to enhance social protection' (Reuters 2014), particularly in the form of 'social spending floors' (IMF 2008; 2015b). These conditions stipulate a minimum of social spending - primarily on health and education - and have been a cornerstone in the IMF's purported attention to the social consequences of its policy advice (Clegg 2014). Indeed, a recent study by IMF staff found that Fund programmes are associated with increases in social spending in low-income countries (Clements, Gupta, and Nozaki 2013). A series of internallygenerated studies also report flattering results on the organization's impact on social protection policies (Clements, Gupta, and Nozaki 2014; Gupta 2010; 2015).

Is the organization correct to proclaim that it has addressed criticisms and adapted the policies attached to its financial assistance packages? Or are critics accurate in their portrayal of the IMF as 'going backwards' (Griffiths and Todoulos 2014) by impinging on countries' politics and adversely affecting sensitive policy areas? The remainder of this paper examines the evolution of IMF conditionality, and presents evidence that directly addresses these two controversies.

\section{Development policy space under IMF programmes}

To investigate the evolution of conditionality, we draw on IMF archival documents covering the years 1985-2014. In total, we searched 4,590 loan-related documents ${ }^{6}$ to extract 55,465 conditions spread across 131 countries. These documents consisted of IMF staff reports, national governments' Letters of Intent, and accompanying Memoranda of Economic and Financial Policies, which specify conditionality. Documents are generally updated with additional conditions on three- or six-month review cycles (although delays are common), and the successful conclusion of reviews determines the disbursement of loan tranches. In this

\footnotetext{
${ }^{6}$ These documents also include those that relate to the post-2010 loans to Eurozone countries, designed jointly by the IMF, the European Commission, and the European Central Bank. The division of labour within the Troika - and, therefore, accountability for the outputs - was not clearly demarcated. However, while it is clear that both the IMF and the European Commission had a role in the design of structural conditionalities (IMF 2013a)some observers have pointed out the IMF's junior role in the Troika (Pisani-Ferry, Sapir, and Wolff 2013). Future analyses can explore in greater detail where the organization had most influence in the design of the Eurozone adjustment programmes. The Eurozone conditionalities referred to here were all identified in IMF documents (rather than European Commission reports).
} 
section, we focus on the number of conditions applicable per country-year; we discuss methodological issues related to data collection in Appendix I.

Before presenting our findings, a word of caution is warranted. Reporting the number of conditions, while revealing, is an imperfect measure of conditionality. For example, a condition stipulating the privatization of a state-owned enterprise is qualitatively distinct from one introducing a value-added tax. Despite this, previous studies have shown the measure is a suitable proxy for the intrusiveness of conditionality (Caraway, Rickard, and Anner 2012; Copelovitch 2010; Dreher and Jensen 2007; Dreher, Sturm, and Vreeland 2009; 2015), and it has been fruitfully employed in the IMF's own studies (Bulir and Moon 2004; Ivanova et al. 2001). We proceed with this indicator to yield inferences about important aspects of the IMF's policy advice: the evolution of conditionality, changes to the use of so-called structural conditions, and patterns in the breadth of policy areas targeted by IMF conditionality. In the subsequent section, we focus on country-specific experiences to revisit controversies surrounding labour issues and social protection.

\section{(a) The evolution of conditionality}

In Figure 1, we present countries' total number of conditions applicable in all IMF loans between 1985 and 2014. During this period, Romania, Pakistan, Tanzania, Kyrgyzstan and several West African countries emerge as those with highest overall conditionality burdens: all had repeat loans that carried a high degree of conditionality. Furthermore, we observe widely diverging experiences with IMF conditionality across countries. For example, Mauritania had IMF programmes for 25 of the 30 years covered, carrying a total of 1,058 conditions. Other countries had only brief encounters with the Fund, which is also reflected in relatively limited conditionality. For instance, China only had a one-year Stand-by Arrangement - the IMF's staple lending facility — with 28 conditions attached between 1986-87.

[Figure 1 here]

Table 1 offers some indication of how conditionality has evolved in the period covered by our data. The number of conditions in IMF programmes active per calendar year rose in the late 1980s, reaching a median of circa 42 conditions applicable per year over 1996-2007. Subsequently, we observe a reduction in the median of conditions to 33-35 in the immediate post-crisis period. Despite this apparent decline, we note an increase in high conditionality programmes. Afghanistan, Bangladesh, Bosnia, Cote d'Ivoire, Ghana, Greece, Haiti, Jamaica and the Ukraine have all carried 60 or more conditions at least once since 2009. In 2014, the median of conditions jumped to 44, the third highest such figure in our dataset after 2003 (median of 45 conditions) and 2004 (median of 47 conditions). Moreover, several Eastern European and Central Asian countries represent high-lying outliers, peaking at over 140 conditions for Russia in 1998 and Ukraine in 1999. Despite the fact that most post-communist countries started implementing IMF reform programmes in the early-1990s, only in the latter half of the decade did conditionality expand greatly in degree and scope.

[Table 1 here]

This evidence documents a slight reduction in IMF programme conditionality over the period following the onset of the global financial crisis, even though it remained considerably higher 
than the 1980s and early-1990s. The most recent data reveal a rising trend for the burden of conditionality since 2008. At the same time, while we notice this increase in conditionality, there has also been a marked decline in the number of lending programmes (new or in progress). A spike in post-crisis lending was followed by a decline in demand for IMF services. Of the 35 lending programmes active in 2014, 13 were to Sub-Saharan African countries and 10 were to European and Central Asian countries. Lending to Latin America or East Asia - common in the past-has declined considerably. Only 5 countries from these two regions had IMF programmes in 2014, compared 16 countries in 2000.

\section{(b) The rise, fall and return of structural conditionality}

The technical apparatus of conditionality has also evolved over time, with direct implications for the policy space available to borrowing countries. To determine the disbursement of loan tranches, IMF lending programmes make use of two types of conditions: quantitative and structural (Bird 2009; IMF 2015a). Originally, IMF conditions only appeared in the form of quantifiable macroeconomic targets (e.g., limits to government borrowing). While such conditions still form the bulk of conditionality up to the present, they only specify the policy ends rather than the means. That is to say, although quantitative conditions may be overly restrictive, in theory governments can pursue a range of alternative policies to meet them. In contrast, structural reforms clearly specify means that contribute to meeting the macroeconomic targets and other objectives.

In this section, we examine evidence on structural conditionalities; that is, IMF-mandated reforms aimed at "reducing or dismantling government-imposed distortions or putting in place various institutional features of a modern market economy" (Goldstein 2003:366). Such reforms have commonly aimed at altering the underlying structure of an economy; for instance, by privatizing state-owned enterprises, legislating central bank independence, deregulating labour markets, or restructuring tax systems. These conditions can be distinguished vis-à-vis their strictness. Binding conditions-known as prior actions and structural performance criteria - form sine qua non criteria for continued financial assistance, and apply to areas that Fund staff consider 'crucial to the success of the program' (Leckow 2002). In cases of nonimplementation, countries must request a waiver by the IMF's Executive Board, an action that could damage countries' reputation in international markets (Andersen 2009). In contrast, nonbinding structural conditions - known as benchmarks - are also envisaged to apply only to policy areas 'critical' to the objectives of lending programmes, but rely on the discretionary assessment by staff (Goldstein 2001; Guitián 1995).

As shown in Figure 2, structural conditionality has evolved over time. Starting from very low levels in the mid-1980s, within a decade the use of such policies expanded rapidly and peaked at about 16 structural conditions on average in 1998-99. That peak also marked the height of criticisms of the IMF's policy advice, and eventually resulted in the launch of the 'streamlining initiative' (IMF 2001). Since then, the mean of structural conditions per year remained around 12, followed by a sharp drop in 2008, partly explained by the phasing out of structural performance criteria (IMF 2009f). The latter was followed by an upsurge in structural benchmarks. Excluding the 2008 outlier, the trend for these benchmarks has been to increase recently (see also IEO (2014:29)). In 2014, more structural benchmarks were included in IMF 
programmes than in any other year. Another development has been the gradual reduction of prior actions (the strictest type of conditions) between 1999 and 2007. In 2011, however, we observe a reversal of the downward-sloping trend. Overall, the total number of structural conditions reached 12.1 in 2014, identical to the mean of the 2001-07 period.

[Figure 2 here]

These trends suggest that structural adjustment is not a policy fad of the past with no relevance to contemporary IMF practices. The organization's programmes still incorporate a considerable number of structural conditions, and the total number of such conditions still far exceeds that observed in the pre-1994 period. The emphatic return of structural conditionality in recent years calls into question the IMF's 'we don't do that any more' rhetoric.

\section{(c) Scope of conditionality}

While trends in the total number or type of conditions are suggestive, adequately assessing IMF policy prescriptions requires exploring in greater detail their distribution in different policy areas (Bird 2009). To do so, we build on a growing literature (Dreher et al. 2015; IEO 2007a; 2007b; Stone 2008), and examine the 'scope' of IMF conditionality: how many policy areas are subject to reform in IMF programmes? Such metrics speak directly to issues of mission creep examined above, as critics argue that IMF conditionality has veered into an evergrowing number of policy areas. Building on conventions in the literature (IEO 2007a), we identified the scope of reforms by classifying all conditions into mutually-exclusive policy areas, summarised in Table 2.

[Table 2 here]

Figure 3 presents the share of IMF programmes with at least one condition per policy area in a given year. As IMF programs in all years include conditions in core areas of the organization's competence (financial sector, monetary policy, fiscal policy, revenues and taxation, and debt issues), we have not included these shares in the figure. ${ }^{7}$ An initial observation is that the expansion of conditionality started in the mid-1980s, prompted by the push of the United States for programmes to include a structural, supply-side orientation and the associated introduction of the Structural Adjustment Facility (Babb 2009; Boughton 2001; Toye 1994). We examine the evolution of IMF-mandated reforms in different policy areas in turn, supplementing the quantitative data with additional country-specific evidence from recent IMF conditionality. Labour and social protection issues are examined separately and in greater depth in the subsequent section.

[Figure 3 here]

\footnotetext{
7 Although IMF programmes have always devoted attention to these areas, the nature of the organization's policy advice has evolved over time. For instance, the IMF's tax policy advice has changed significantly over the decades: from an initial period of merely stipulating tax revenue targets to eventually designing tax policy, including the introduction of VAT and the reduction of trade-related taxes (Broome and Seabrooke 2007; Polak 1991; Seabrooke 2010). It is beyond the scope of this article to examine these issues.
} 
First, the IMF — an organization with a 'globalizing mission' (Woods 2006) — has become known for its advocacy of trade and financial liberalization. Indeed, this was reflected in IMFmandated reforms, with over $80 \%$ of programmes between 1990 and 2004 including conditions to that effect. Initially, conditions focused on the removal of tariffs and other import restrictions, but over time they expanded to cover issues of capital account liberalization. Yet, as is well-documented (Chwieroth 2013; Gallagher 2011; 2014; Gallagher and Ocampo 2013; Grabel 2011; 2014), the IMF changed its 'house view' on capital mobility, and - in the past decade - we could not find an instance of a condition advocating capital account liberalization. ${ }^{8}$ More generally, our evidence reveals a decline in external sector conditions (these now mostly refer to targets for holdings of international reserves). The changed views over capital mobility offer one plausible explanation for this drop. However, it is also the case that many economies have, by now, already opened up to international markets (often under IMF guidance), and have entered into numerous bilateral investment treaties envisaging capital mobility (Neumayer and Spess 2005), so the need - from the IMF's standpoint - to impose related conditions has diminished.

Second, a recurring controversy surrounding IMF programmes concerns their purported bias against state-owned enterprises (SOEs), considered as prone to mismanagement and inefficiencies (see Toye 1994). Reforms in this sector have been present in most IMF programmes since the late-1980s. Consistent with the timing of the post-communist transitions (and the IMF's heavy involvement in the process), a height of 70-80\% of programmes included at least one SOE-related condition in the mid- and late-1990s. In more recent years, about 50$60 \%$ of programmes stipulate SOE reforms or privatizations. On the one hand, these declines could correspond to a narrowing of the scope of conditionality, as per IMF rhetoric (IMF 2012a; 2013b). On the other hand, it may also be the case that after decades of countries corporatizing, privatizing or liquidating publicly-owned firms at the behest of the IMF (Brune, Garrett, and Kogut 2004), there is less room for further such reforms.

Evidence from conditionality in recent IMF programmes lends credibility to the second explanation. The IMF's repeat borrowers ${ }^{9}$ had a median of 2 SOE-related conditions per year under IMF programmes between 1985 and 2008, compared to a median of 0 such conditions per year under IMF programmes between 2009 and 2014. In contrast, new borrowers ${ }^{10}$ had a

\footnotetext{
${ }^{8}$ In relation to capital controls, while the IMF accepted their utility in the case of the Icelandic crisis (Grabel 2014), the country's 2009 conditionality stipulated the "approval by cabinet of a strategy to phase out capital controls" (IMF 2009d). Yet, the IMF acknowledged that this should be done in a gradual manner.

${ }^{9}$ To our knowledge, there is no established definition of a repeat borrower. Here, we use the term to refer to countries with 19 or more years under IMF programmes out of our 30-year coverage (19852014), with at least one year since 2009. This definition yields a total of 23 countries: Armenia, Benin, Burkina Faso, Burundi, Cote d'Ivoire, Gabon, The Gambia, Georgia, Ghana, Guinea, Haiti, Kyrgyz Republic, Lesotho, Malawi, Mali, Mauritania, Mozambique, Niger, Pakistan, Romania, Senegal, Sierra Leone, and Tanzania.

${ }^{10}$ New borrowers are defined here as countries with 8 or fewer years under IMF programmes out of our 30-year coverage (1985-2014) and having an IMF programme at least one year since 2009.
} 
median of 1 condition per year under IMF programmes between 2009 and 2014. Recent key examples include the establishment of a privatization agency and preparation of a privatization plan for SOEs in Belarus (IMF 2010e), the privatization of the Kosovar state-owned telecommunications company (IMF 2010f), and a range of reforms to government enterprises in Antigua and Barbuda, the Solomon Islands, and St. Kitts and Nevis (IMF 2010a; 2011b; 2012f). Beyond these cases, IMF conditionality in Eurozone countries has also mandated privatizations or SOE reforms.

Finally, the IMF has long taken an interest in so-called institutional reforms aimed at promoting a 'business-friendly' environment, notwithstanding doubts over whether certain such arrangements are desirable or exportable (Rodrik 2002; Stiglitz 2002). Conditions in this broad policy area were common from the 1990s into the late-2000s, and covered reforms to legal systems, competition law, business regulation, environmental policies (including natural resources) and social protection issues. The early years of the crisis were marked by a drop in the inclusion of such reforms, showcased in the organization's recent review of conditionality (IMF 2012a). Yet, this downwards trend reversed in 2010. By 2014, 63\% of all programmes include one or more such institutional reforms.

Similar to the experience with SOE-related conditionality outlined above, we observe differences in repeat versus new IMF borrowers. Repeat borrowers had an average of 1.0 institutional reform conditions per year under IMF programme between 1985 and 2008, ${ }^{11}$ compared to only 0.6 such conditions per year under IMF programme between 2009 and 2014. New borrowers had an average of 1.0 institutional reforms between 2009 and 2014 For instance, the 2014 Tunisian adjustment programme mandated passing a 'decree for implementing the new investment code in line with the objective of protecting market access, reducing restrictions on investments, and rationalizing of incentives' (IMF 2014h). Similar reforms were designed for Guinea, Cote d'Ivoire, Niger and elsewhere. Ukraine's recent conditionality also stipulated that 'the government will adopt an action plan to eliminate, streamline, simplify and clarify the legislative and regulatory frameworks governing economic activity' (IMF 2014i). Likewise, the Armenian parliament was asked to adopt regulatory reforms in a range of policy areas, including entrepreneurship, customs, and social issues (IMF 2014a).

In sum, the evidence presented in this section reveals that only limited progress has been made in trimming down conditionality. While IMF programmes are not as all-encompassing as they were during the 1993-2007 period, still more than half stipulate reforms to state-owned enterprises and institutional environments. Further, the decline in the scope of conditionality is, in part, explained by the years a country has spent under IMF programmes. Repeat borrowers have already had to implement extensive conditionality over the years prior to the crisis, andas a result-there is less 'need' for such conditions to be introduced in recent IMF programmes. That is to say, what could - in the first instance - be interpreted as a narrowing scope of conditionality in the pre-crisis period is also evidence of a 'job done' by the IMF over

\footnotetext{
${ }^{11}$ Here, we use means rather than medians because the median was 0 for repeat borrowers 1985-2008 and 2009-14 and for new borrowers 2009-14.
} 
more than two decades of structural adjustment programmes. Finally, the recent incidence of high-conditionality programmes and the increases in structural conditionality across IMF loans represent a key discrepancy between rhetoric and practice by the organization.

\section{Plus ça change: Labour issues and social protection in recent IMF programmes}

Having surveyed the general trends in conditionality, this section examines in greater detail the IMF's policy advice in two areas that have attracted considerable attention in recent years: labour issues and social protection. First, a notable development of the past decade has been the rapid rise in the inclusion of poverty-reduction conditions (Figure 3). While fewer than $10 \%$ of IMF programmes included such conditions until 1997, since then the use of these instruments has become prevalent. Since 2012, about $70 \%$ of all programmes included at least one such condition. Commonly, the conditions included in this category are formulated as 'priority expenditure floors' specifying minimum expenditures on health, education and other social policies. The inclusion of such conditions marks a sharp shift from past practices, when the IMF was accused of neglecting the social consequences of its programmes. Second, on labour issues, after a period of relative indifference until the early 1990 s, about $50 \%$ or more of lending programmes have carried at least one labour-related condition over the 1994-2007 period. Interestingly, a peak for these types of reforms is noted in 2004 (included in over 70\% of lending programmes), primarily reflecting conditions limiting the public sector wage bill. Since then, labour-related conditionality has declined, with circa $25-40 \%$ of programmes advocating such reforms in recent years.

On the surface, this evidence on labour-related and pro-poor conditionality suggests that policy practice matches rhetoric, and that the IMF has fundamentally reformed the priorities of its policy advice. But how much of a difference have these apparent changes made on the ground? Here, we move beyond counting conditions to examine the exact policy content of recent programmes.

\section{(a) Social issues}

The IMF has long claimed that it is concerned about the social consequences of its policy advice (Camdessus 1998; de Larosière 1986; de Rato 2006), and that its programmes include adequate safeguards to ensure the protection of the poor (Gupta et al. 2000; IMF 1995; 2008; 2013d; 2014f; 2015b). Indeed, poverty reduction was recognized in the name of the organization's standard lending facility for low-income countries, the Poverty Reduction and Growth Facility (until 1999 known as the Enhanced Structural Adjustment Facility, and since 2009 known as the Extended Credit Facility). Countries receiving financial support through this instrument were required to produce 'Poverty Reduction Strategy Papers' (Stewart and Wang 2003), and the design of conditionality also incorporated explicit measures to maintain or increase of social expenditures, as shown above (Figure 3). The inclusion of these policies in IMF-supported programmes does not in itself provide concrete evidence that rhetoric matches practice, as it could just be a smokescreen designed to deflect criticism.

To examine the issue, we collected detailed data on the implementation of social spending floors applicable to IMF programmes in Sub-Saharan African countries-where most such 
conditions applied - since 2000. In total, we identified 472 such conditions applicable in 29 countries (often on a quarterly or biannual basis), and present our findings grouped by subregion. As shown in Table 3, we could only trace implementation data for 362 of these conditions and nearly half were not implemented. In particular, the West African region recorded the poorest implementation, showing non-observance of 54\% of social spending floors with available data.

[Table 3 here]

According to some academic observers, the non-implementation of social spending targets is linked to the lack of capacity or interest by borrowing countries (e.g. Blattman 2014). Extending this line of argument, even if governments choose not to meet these conditions, the IMF will continue to provide financial support as long as the programme's fiscal and financial targets are achieved. Indeed, social expenditure floors almost always feature as non-binding conditions, so their non-implementation does not necessarily affect access to IMF credit. While such an account is plausible, it neglects the potential contradictions in the IMF's policy advice (e.g., overly restrictive macroeconomic targets may limit funds available for social protection) and conflicting statements from countries suggesting a desire to increase spending (e.g., by agreeing on spending increases in international fora). To evaluate this issue, we examined whether countries with the poorest implementation records on priority spending conditions were able to meet budget balance conditions. As Table 4 shows, budget balance conditions were consistently adhered to and often were far-exceeded, while at the same time social spending floors remained unmet.

[Table 4 here]

The experience of high-income European countries also merits attention. All four recent Eurozone adjustment programmes-designed jointly by the IMF, the European Commission, and the European Central Bank-contained a set of measures aimed at reducing social spending and increasing revenues. The health sector attracted particular attention in these lending programmes, and provides a case in point. Countries with were asked to introduce a mix of health sector cuts, introduce (or increase) user fees, and tighten eligibility criteria for access to services (Kentikelenis 2015; Kentikelenis, Karanikolos, et al. 2014b). Despite this, the IMF selected the Greek case as a showcase of 'how IMF-supported programs seek to protect social spending in a way that is both fiscally-sustainable and cost-effective' (IMF 2015b). The organization highlights that 'several schemes have been put in place to provide free healthcare access, including health vouchers, poverty booklets, and universal health care coverage for the uninsured' (IMF 2015b). Yet, recent evidence on each of the cited measures suggests that none have lived up to their promise, in part due to overly stringent or out-dated eligibility criteria (Economou et al. 2014; Kentikelenis 2015).

The inadequate implementation of priority spending targets - often while budget balance conditions were far exceeded - and the evidence from recent lending suggests that the IMF has not lived up to its own hype of promoting social protection. While some progress has been made, blanket statements that 'under IMF-supported programs, the Fund helps governments to protect and even increase social spending' (IMF 2015b) are not supported by the data. Further, the organization's view of social protection emphasises targeted social assistance (IMF 2014f; 
2015b) at a time when global policy debates around the Sustainable Development Goals are overwhelmingly focused towards the universal provision of key welfare services (ILO 2014a; 2014b; UN 2012; WHO 2013; 2014).

\section{(b) Labour issues}

The IMF has changed its rhetoric both over the limits on government spending on salaries and over the merits on labour market policies. According to its staff, wage bill ceilings have been discontinued (Gupta 2015), and labour market policies are peripheral to many of its programmes (IMF 2014b). How do such statements square with the IMF's policy advice on labour market issues in recent years? We draw on evidence from post-2008 IMF programmes, and examine the experience of developing and high-income countries in turn.

A close examination of IMF conditionality in developing countries reveals that the IMF's involvement on issues directly affecting labour is not limited, despite claims to the contrary. For instance, wage bill ceilings - while used less than in the past - have still been part of IMF programmes in Cote d'Ivoire (2009-13), Honduras (2010-11) and Moldova (2010-12). These conditions were incorporated into IMF programmes in a non-binding form (benchmarks), but were still considered by IMF staff as 'critical' enough for inclusion into conditionality. In particular, Moldova's IMF-designed labour-related reforms included measures to 'optimize the number of employees in the budgetary sector [... by] eliminat[ing] at least 4,000 positions' in 2010 (IMF 2010g:7), as well as further policy changes that affected civil servants (IMF 2012e).

Moreover, a number of countries' adjustment programmes included extensive pension reforms. Romania's programme targeted pensions, including a 15\% cut and a number of further changes to the system that would reduce pay-outs and raise the retirement age (IMF 20101). The measures proved controversial (Reuters 2010), and were struck down by the country's constitutional court (IMF 20101). Yet, a few months later, the same reform package was reintroduced as a binding prior action stipulating the "parliamentary approval of pension reform legislation' (IMF 2010j), and was eventually passed despite objection from the Romanian president (IMF 2010k). Similarly, Serbia's conditionality introduced a pension freeze between 2009 and 2011 (IMF 2009g; 2010h), and increased retirement ages (IMF 2010i).

The recent IMF programmes in Eurozone countries have also relied on labour-related reforms, including on deregulation, government wage spending, and social security systems. For instance, Greece's conditionality stipulated extensive labour market liberalization. The country's programme included reforms - often as prior actions - to the collective bargaining system, the precedence of firm-level (as opposed to sectoral) agreements, and the reduction of minimum wages and employee dismissal costs (IMF 2010d; 2010c; 2012c; 2012b; 2014d). Similarly, Portugal's adjustment programme stipulated increases to the retirement age, weakening of collective bargaining, and the introduction of a 'public administration labour law that will aim at aligning current public employment regime to the private sector rules..., and termination of tenure' (IMF 2012d; 2013c; 2014e).

In sum, this overview of recent IMF conditionality on social protection and labour issues suggests that the organization's claims of fundamental changes to conditionality are exaggerated. Delving into the exact policy content of IMF programmes, we find much of the 
same policy advice that has been at the centre of controversies for decades, and we show that the advertised attention to social protection issues reflects more 'talk' than 'walk.' At the same time, the links outlined above likely understate the true magnitude of the IMF's effects on labour and social protection policies: austerity measures and misconceived structural reforms may carry indirect - but still tangible - effects that are not captured in the pathways outlined above (see Kentikelenis, Stubbs, and King 2015). ${ }^{12}$

\section{Conclusions}

This paper utilized newly available data on IMF conditionality to revisit key debates over the organization's policy advice to its borrowers. Our findings suggest that the IMF's claim that programmes now 'creat[e] policy space' by exhibiting 'responsive design and streamlined conditionality' (IMF 2009c) is not an accurate representation of reality. The period of organizational insecurity preceding the global financial crisis was linked to changes in the IMF's policy prescriptions, reflected in declines in conditions attached to its loans. However, as the crisis progressed, the IMF re-emerged as a central organization dealing with the policy response, and - following this boost in organizational self-confidence - the downward trend in conditionality reversed. Martin Wolf's (2011) pessimistic premonition that the 'new [and] cuddly' IMF 'can't possibly last' is confirmed by our data. In particular, structural conditionality has returned as a key component of IMF programmes and its scope has been widening in recent years. Further, we investigated in greater detail whether the apparent shift in the IMF's practice over labour and social protection matched the evidence from country lending agreements. Our evidence offers grounds for scepticism. First, despite consistent rhetoric to the contrary, the IMF still advocates reforms that aim at labour market liberalization, public sector employment reduction, or reductions in government wage spending. Second, while IMF programmes now often include 'pro-poor' measures in the form of social spending floors, in practice these measures are only superficially incorporated into programme design. Data from social expenditure targets in Sub-Saharan Africa shows that they remain unmet half of the time, even while fiscal deficit targets are achieved. Such findings suggest that the IMF's pro-poor concerns are accorded, at best, secondary importance compared to macroeconomic targets.

We note three limitations of our work. First, we have purely examined the 'supply' of conditionality and weighed it against rhetoric. It is possible that some governments requested specific policy conditions to overcome domestic opposition to reforms (Güven 2012; Vreeland 2003), and that some programmes were interrupted or not fully implemented (Arpac, Bird, and Mandilaras 2008). Future research can explore these issues in greater depth. Second, we focus our analysis mostly on the structural reform component of IMF programmes. The IMF's

\footnotetext{
${ }^{12}$ Indirect pathways relate to the collateral damage of overly stringent IMF macroeconomic policy advice. For example, even if the level of pensions - classified as a labour issue in our data-is not explicitly targeted by an IMF programme, in the context of overall austerity it is plausible that some governments will opt to reduce pensions to cut down on public expenditure. Such pathways are difficult to uncover relying on our IMF documentation, and require country-specific research.
} 
macroeconomic policy advice - e.g., on the speed or extent of fiscal consolidation - is equally important. This has been explored by other recent studies (Grabel 2011; Ortiz, Chai, and Cummins 2011; Weisbrot et al. 2009) which found evidence of pro-cyclical policy advice that reduced fiscal policy space for governments. Finally, conditionality represents only the most visible set of IMF-induced policy constraints facing the organization's borrowers. Indeed, IMF programmes include non-coercive advice in the form of technical assistance or policy recommendations. The extent to which such advice is actually taken on-board remains unclear.

Our study has provided evidence of important gaps between rhetoric and practice in key aspects of the IMF's lending activities. We argue that these are manifestations of an escalating commitment to hypocrisy. Intergovernmental organizations produce hypocrisy to safeguard their legitimacy, gain access to resources, and placate critics. As they do so, they become locked-in on a specific course of action, which-in turn-yields a layering process of ceremonial reforms. The IMF's involvement in low-income countries illustrates this point. In the late-1990s, following criticisms of the organization's structural adjustment programmes, the IMF rebranded its lending instrument as the Poverty Reduction and Growth Facility, and introduced 'social spending floors' to allay concerns over insufficient attention to the social consequences of its programmes. Then, in the early-2000s the IMF's rhetoric emphasised its commitment to 'creating policy space' via 'streamlined conditionality.' Finally, after the onset of the global financial crisis, IMF programmes were purportedly 'flexible' and 'tailored to country needs,' not bearing any semblance to structural adjustment policies advocated in the past in the past, as Christine Lagarde points out in the opening quote. These iterative layers of rhetoric and ceremonial reforms are - in part-an attempt to maintain the myth of the fundamentally reformed institution.

Documenting the production of layers of hypocrisy is the first step of a broader research agenda. The next step is unearthing exactly how these layers are produced (see Weaver 2008). Is this process spearheaded by management in collaboration with public affairs departments? Are middle- or low-ranking staff involved? And do the states overseeing the activities of these organizations condone or ignore such actions? Future research can examine these issues.

The reform of the IMF's practices and governance has been a topic of sustained controversy in international economic policy circles. We have shown that the organization has been particularly adept at introducing ceremonial pretences of reform. On the contrary, the organization's own advice to countries has been to build up the political will and perseverance to carry out difficult structural reforms; this advice can now be turned inwards.

\section{Bibliography}

Abouharb, M. R. and D. Cingranelli. 2007. Human Rights and Structural Adjustment. Cambridge: Cambridge University Press.

Andersen, C. 2009. "New Rules of Engagement for IMF Loans." IMF Survey. Retrieved September 8, 2014 (http://www.imf.org/external/pubs/ft/survey/so/2009/pol041309a.htm). 
Arpac, O., G. Bird, and A. Mandilaras. 2008. "Stop Interrupting: an Empirical Analysis of the Implementation of IMF Programs.” World Development 36(9):1493-1513.

Babb, S. L. 2005. "The Social Consequences of Structural Adjustment: Recent Evidence and Current Debates.” Annual Review of Sociology 31(1):199-222.

Babb, S. L. 2009. Behind the Development Banks: Washington Politics, World Poverty, and the Wealth of Nations. Chicago: University of Chicago Press.

Babb, S. L. 2013. "The Washington Consensus as Transnational Policy Paradigm: Its Origins, Trajectory and Likely Successor." Review of International Political Economy 20(2):26897.

Babb, S. L. and A. Buira. 2005. "Mission Creep, Mission Push and Discretion: the Case of IMF Conditionality." Pp. 59-84 in The IMF and the World Bank at sixty, edited by A. Buira. London: Anthem.

Babb, S. L. and B. G. Carruthers. 2008. "Conditionality: Forms, Function, and History." Annual Review of Law and Social Science 4(1):13-29.

Ban, C. 2015. "Austerity Versus Stimulus? Understanding Fiscal Policy Change at the International Monetary Fund Since the Great Recession.” Governance 28(2):167-83.

Ban, C. and K. P. Gallagher. 2015. "Recalibrating Policy Orthodoxy: the IMF Since the Great Recession." Governance 28(2):131-46.

BBC. 2009. “The International Monetary Fund Returns.” Retrieved May 16, 2015 (http://news.bbc.co.uk/1/hi/business/8015979.stm).

Berg, A. et al. 2009. "Fiscal Policy in Sub-Saharan Africa in Response to the Impact of the Global Crisis." IMF Staff Position Note (SPN/09/10).

Bird, G. 2009. "Reforming IMF Conditionality.” World Economics 10(3):81-104.

Blanton, R. G., S. L. Blanton, and D. Peksen. 2015. "The Impact of IMF and World Bank Programs on Labor Rights.” Political Research Quarterly.

Blattman, C. 2014. "Did the International Monetary Fund Help Make the Ebola Crisis?." The Washington Post. Retrieved January 6, 2015

(http://www.washingtonpost.com/blogs/monkey-cage/wp/2014/12/30/did-theinternational-monetary-fund-help-make-the-ebola-crisis/).

Boughton, J. M. 2001. Silent Revolution: International Monetary Fund, 1979-1989. Washington DC: International Monetary Fund.

Broome, A. 2014. "Back to Basics: the Great Recession and the Narrowing of IMF Policy Advice." Governance 28(2):147-65. 
Broome, A. and L. Seabrooke. 2007. "Seeing Like the IMF: Institutional Change in Small Open Economies.” Review of International Political Economy 14(4):576-601.

Brune, N., G. Garrett, and B. Kogut. 2004. "The International Monetary Fund and the Global Spread of Privatization." IMF Staff Papers 51(2):195-219.

Brunsson, N. 1989. The Organization of Hypocrisy: Talk, Decisions, and Actions in Organizations. Chichester: J WIley \& Sons.

Brunsson, N. 1993. "Ideas and Actions: Justification and Hypocrisy as Alternatives to Control." Accounting, Organizations and Society 18(6):489-506.

Brunsson, N. 2003. "Organized Hypocrisy.” Pp. 201-22 in The Northern Lights: Organization Theory in Scandinavia, edited by B. Czarniawska-Joerges and G. Sevón. Copenhagen: Copenhagen Business School Press.

Bukovansky, M. 2010. "Institutionalized Hypocrisy and the Politics of Agricultural Trade." Pp. 68-89 in Constructing the international economy, edited by R. Abdelal, M. Blyth, and C. Parsons. Ithaca: Cornell University Press.

Bulir, A. and S. Moon. 2004. "Is Fiscal Adjustment More Durable When the IMF Is Involved?." Comparative Economic Studies 46(3):373-99.

Camdessus, M. 1998. "Addressing Concerns for the Poor and Social Justice in Debt Relief and Adjustment Programs.” International Monetary Fund. Retrieved June 12, 2015 (https://www.imf.org/external/np/speeches/1998/102298.htm).

Caraway, T. L., S. J. Rickard, and M. S. Anner. 2012. "International Negotiations and Domestic Politics: the Case of IMF Labor Market Conditionality." International Organization 66(1):27-61.

Chang, H.-J. 2006. "Policy Space in Historical Perspective with Special Reference to Trade and Industrial Policies." Economic and Political Weekly 41(7):627-33.

Chwieroth, J. M. 2013. "Controlling Capital: the International Monetary Fund and Transformative Incremental Change From Within International Organisations." New Political Economy 19(3):445-69.

Clegg, L. 2014. "Social Spending Targets in IMF Concessional Lending: US Domestic Politics and the Institutional Foundations of Rapid Operational Change." Review of International Political Economy 21(3):735-63.

Clements, B., S. Gupta, and M. Nozaki. 2013. "What Happens to Social Spending in IMFSupported Programmes?.” Applied Economics 45(28):4022-33.

Clements, B., S. Gupta, and M. Nozaki. 2014. "What Happens to Public Health Spending in IMF-Supported Programs? Another Look.” International Monetary Fund. Retrieved 
December 31, 2014 (http://blog-imfdirect.imf.org/2014/12/21/what-happens-to-publichealth-spending-in-imf-supported-programs-another-look/).

Colclough, C. and J. Manor, eds. 1991. States or Markets? Neo-Liberalism and the Development Policy Debate. Oxford: Oxford University Press.

Cooper, R. N. 1968. The Economics of Interdependence: Economic Policy in the Atlantic Community. New York: McGraw-Hill.

Copelovitch, M. S. 2010. "Master or Servant? Common Agency and the Political Economy of IMF Lending.” International Studies Quarterly 54(1):49-77.

Cornia, G. A., R. Jolly, and F. Stewart, eds. 1987. Adjustment with a Human Face: Volume I: Protecting the Vulnerable and Promoting Growth. Oxford: Oxford University Press.

Dabla-Norris, E., G. Ho, K. Kochhar, A. Kyobe, and R. Tchaidze. 2013. "Anchoring Growth: the Importance of Productivity-Enhancing Reforms in Emerging Market and Developing Economies ." IMF Staff Discussion Note SDN/13/08.

Dabla-Norris, E., K. Kochhar, N. Suphaphiphat, F. Ricka, and E. Tsounta. 2015. "Causes and Consequences of Income Inequality: a Global Perspective." IMF Staff Discussion Notes $15 / 13$.

de Larosière, J. 1986. "Statement by the Managing Director of the International Monetary Fund." United Nations University. Retrieved May 21, 2015 (http://archive.unu.edu/unupress/food/8F091e/8F091E0c.htm).

de Rato, R. 2006. "Renewing the IMF's Commitment to Low-Income Countries." IMF. Retrieved November 29, 2014 (http://www.imf.org/external/np/speeches/2006/073106.htm).

Dell, S. 1981. "On Being Grandmotherly: the Evolution of IMF Conditionality.” Princeton Essays in International Finance 144(October).

Dell, S. 1982. "Stabilization: the Political Economy of Overkill." World Development 10(8):597-612.

Diaz-Alejandro, C. F. 1981. "Southern Cone Stabilization Plans.” Pp. 119-47 in Economic stabilization in developing countries, edited by W. R. Cline and S. Weintraub. Washington DC: The Brookings Institution.

DiCaprio, A. and K. P. Gallagher. 2006. "The WTO and the Shrinking of Development Space." Journal of World Investment and Trade 7(5):781-803.

Dreher, A. 2009. “IMF Conditionality: Theory and Evidence.” Public Choice 141(1-2):233-67.

Dreher, A. and N. M. Jensen. 2007. "Independent Actor or Agent? an Empirical Analysis of the Impact of U.S. Interests on International Monetary Fund Conditions." The Journal of 
Law and Economics 50(1):105-24.

Dreher, A., J.-E. Sturm, and J. R. Vreeland. 2009. "Global Horse Trading: IMF Loans for Votes in the United Nations Security Council." European Economic Review 53(7):742-57.

Dreher, A., J.-E. Sturm, and J. R. Vreeland. 2015. "Politics and IMF Conditionality." Journal of Conflict Resolution 59(1):120-48.

Economou, C., D. Kaitelidou, D. Katsikas, M. Zafiropoulou, and O. Siskou. 2014. "Impacts of the Economic Crisis on Access to Healthcare Services in Greece with a Focus on the Vulnerable Groups of the Population." Social Cohesion and Development 9(2):99-115.

Fedelino, A., G. Schwartz, and M. Verhoeven. 2006. "Aid Scaling Up: Do Wage Bill Ceilings Stand in the Way? ." IMF Working Paper WP/06/106.

Feldstein, M. 1998. "Refocusing the IMF.” Foreign Affairs 77(2).

Finch, C. D. 1983. "Adjustment Policies and Conditionality.” Pp. 75-86 in IMF

Conditionality, edited by J. Williamson. Washington DC: Institute for International Economics.

Gabor, D. 2010. “The International Monetary Fund and Its New Economics.” Development and Change 41(5):805-30.

Gallagher, K. P. 2010. "Policy Space to Prevent and Mitigate Financial Crises in Trade and Investment Agreements." G-24 Discussion Paper Series 58(May).

Gallagher, K. P. 2011. “The IMF, Capital Controls and Developing Countries.” Economic and Political Weekly XLVI(19):12-16.

Gallagher, K. P. 2014. "Countervailing Monetary Power: Re-Regulating Capital Flows in Brazil and South Korea.” Review of International Political Economy 22(1):77-102.

Gallagher, K. P. and J. A. Ocampo. 2013. "IMF's New View on Capital Controls.” Economic and Political Weekly XLVIII(12):10-13.

Garuda, G. 2000. "The Distributional Effects of IMF Programs: a Cross-Country Analysis." World Development 28(6):1031-51.

Goldsborough, D. 2007. Does the IMF Constrain Health Spending in Poor Countries? Evidence and an Agenda for Action. Washington DC: Center for Global Development.

Goldstein, M. 2001. "IMF Structural Conditionality: How Much Is Too Much?.” Institute for International Economics Working Paper (01-04).

Goldstein, M. 2003. "IMF Structural Programs." Pp. 363-437 in Economic and Financial Crises in Emerging Market Economies, edited by M. Feldstein. Chicago: University of Chicago Press. 
Grabel, I. 2011. "Not Your Grandfather's IMF: Global Crisis, "Productive Incoherence" and Developmental Policy Space.” Cambridge Journal of Economics 35(5):805-30.

Grabel, I. 2014. "The Rebranding of Capital Controls in an Era of Productive Incoherence." Review of International Political Economy 22(1):7-43.

Graeber, D. 2008. "The Shock of Victory: an Analysis of Our Unclaimed Triumphs." Rolling Thunder: an anarchist journal of dangerous living (5):13-20.

Grepin, K. 2015. "Hold Us to Account (as Long as Our Copy Editor Agrees)." Global Health Blog. Retrieved June 12, 2015 (http://karengrepin.com/2015/04/hold-us-to-account-aslong-as-our-copy-editor-agrees.html).

Griffiths, J. and K. Todoulos. 2014. Conditionally Yours: an Analysis of the Policy Conditions Attached to IMF Loans. Brussels: European Network on Debt and Development (Eurodad).

Guitián, M. 1995. “Conditionality: Past, Present, Future.” Staff Papers - International Monetary Fund 42(4):792-835.

Gupta, S. 2010. "Response of the International Monetary Fund to Its Critics." International Journal of Health Services 40(2):323-26.

Gupta, S. 2015. "Response to 'the International Monetary Fund and the Ebola Outbreak'." The Lancet Global Health 3(2):e78.

Gupta, S., L. Dicks-Mireaux, R. Khemani, C. McDonald, and M. Verhoeven. 2000. "Social Issues in IMF-Supported Programs.” IMF Occasional Papers 191.

Güven, A. B. 2012. "The IMF, the World Bank, and the Global Economic Crisis: Exploring Paradigm Continuity." Development and Change 43(4):869-98.

IEO. 2007a. Structural Conditionality in IMF-Supported Programs -- Background Documents. Washington DC: IMF Independent Evaluation Office.

IEO. 2007b. Structural Conditionality in IMF-Supported Programs. Washington DC: IMF Independent Evaluation Office.

IEO. 2011. Research at the IMF: Relevance and Utilization. Washington, DC: IMF Independent Evaluation Office.

IEO. 2014. IMF Response to the Financial and Economic Crisis: an IEO Assessment. Washington, DC: IMF Independent Evaluation Office.

ILO. 2014a. Universal Health Protection: Progress to Date and the Way Forward. Geneva: International Labour Office, Social Protection Department.

ILO. 2014b. World Social Protection Report 2014/15: Building Economic Recovery, Inclusive 
Development and Social Justice. Geneva: International Labour Office.

IMF. 1995. "Social Dimensions of the IMF's Policy Dialogue." IMF Pamphlet Series (47).

Retrieved (https://www.imf.org/external/pubs/ft/pam/pam47/pam47con.htm).

IMF. 1999. Jordan -- Staff Report for the 1999 Article IV Consultation, Request for Extended Arrangement, and Use of Fund Resources -- Request for Purchase Under the Compensatory and Contingency Financing Facility. EBS/99/51 (April 1). IMF Archives.

IMF. 2001. "IMF Managing Director's Report to the International Monetary and Financial Committee - Streamlining Conditionality and Enhancing Ownership." International Monetary Fund. Retrieved May 16, 2015

(https://www.imf.org/external/np/omd/2001/110601.htm).

IMF. 2004. Fund Conditionality - a Provisional Update. Washington, DC: International Monetary Fund.

IMF. 2008. "IMF Helping Countries on Health, Social Spending Policies." International Monetary Fund. Retrieved May 3, 2015

(https://www.imf.org/external/pubs/ft/survey/so/2008/POL072508A.htm).

IMF. 2009a. Annual Report 2009. Washington, DC: International Monetary Fund.

IMF. 2009b. Conditionality in Fund-Supported Programs-Purposes, Modalities, and Options for Reform. Washington, DC: International Monetary Fund.

IMF. 2009c. Creating Policy Space - Responsive Design and Streamlined Conditionality in Recent Low-Income Country Programs. Washington, DC: International Monetary Fund.

IMF. 2009d. "Iceland: Staff Report for First Review Under Stand-by Arrangement and Requests for Extension of the Arrangement." IMF Country Report 09/306.

IMF. 2009e. "IMF Key to Crisis Policy Response, Strauss-Kahn Says.” International Monetary Fund. Retrieved May 16, 2015e (https://www.imf.org/external/pubs/ft/survey/so/2009/NEW042409A.htm).

IMF. 2009f. "New Rules of Engagement for IMF Loans.” IMF Survey. Retrieved May 13, 2015f (https://www.imf.org/external/pubs/ft/survey/so/2009/POL041309A.htm).

IMF. 2009g. Republic of Serbia - Letter of Intent, Memorandum of Economic and Financial Policies, and Technical Memorandum of Understanding (Apr. 30). Washington, DC: International Monetary Fund.

IMF. 2009h. Review of Recent Crisis Programs. Washington, DC: International Monetary Fund.

IMF. 2010a. Antigua and Barbuda: Letter of Intent, Memorandum of Economic and Financial Policies, and Technical Memorandum of Understanding (May 21). Washington, DC: 
International Monetary Fund.

IMF. 2010b. Global Financial Stability Report (April 2010): Meeting New Challenges to Stability and Building a Safer System. Washington, DC: International Monetary Fund.

IMF. 2010c. Greece: Letter of Intent, Memorandum of Economic and Financial Policies, and Technical Memorandum of Understanding (December 8). Washington, DC: International Monetary Fund.

IMF. 2010d. "Greece: Staff Report on Request for Stand-by Arrangement.” IMF Country Report (10/110).

IMF. 2010e. Republic of Belarus: Letter of Intent and Technical Memorandum of Understanding (December 11). Washington, DC: International Monetary Fund.

IMF. 2010f. Republic of Kosovo: Letter of Intent, Memorandum of Economic and Financial Policies, and Technical Memorandum of Understanding (July 7). Washington, DC: International Monetary Fund.

IMF. 2010g. Republic of Moldova: Letter of Intent, Memorandum of Economic and Financial Policies, and Technical Memorandum of Understanding (January 14). Washington, DC: International Monetary Fund.

IMF. 2010h. Republic of Serbia: Letter of Intent and Technical Memorandum of Understanding (March 18). Washington, DC: International Monetary Fund.

IMF. 2010i. Republic of Serbia: Letter of Intent, and Technical Memorandum of Understanding (December 9). Washington, DC: International Monetary Fund.

IMF. 2010j. Romania: Letter of Intent and Technical Memorandum of Understanding (September 9). Washington, DC: International Monetary Fund.

IMF. 2010k. Romania: Letter of Intent, and Technical Memorandum of Understanding (December 22). Washington, DC: International Monetary Fund.

IMF. 20101. Romania: Letter of Intent, Supplementary Letter of Intent of June 29, 2010, and Technical Memorandum of Understanding (June 16). Washington, DC: International Monetary Fund.

IMF. 2011a. Global Financial Stability Report (April 2011): Durable Financial Stability. Washington, DC: International Monetary Fund.

IMF. 2011b. "St. Kitts and Nevis: 2011 Article IV Consultation and Request for Stand-by Arrangement-Staff Report; Staff Supplements; Public Information Notice and Press Release on the Executive Board Discussion; and Statement by the Executive Director for St. Kitts and Nevis." IMF Country Report 11/270.

IMF. 2012a. 2011 Review of Conditionality - Background Paper 1: Content and Application 
of Conditionality. Washington, DC: International Monetary Fund.

IMF. 2012b. 2011 Review of Conditionality - Overview Paper. Washington, DC: International Monetary Fund.

IMF. 2012c. Greece: Letter of Intent, Memorandum of Economic and Financial Policies, and Technical Memorandum of Understanding (December 21). Washington, DC: International Monetary Fund.

IMF. 2012d. Portugal: Letter of Intent, Memorandum of Economic and Financial Policies, and Technical Memorandum of Understanding (June 27). Washington, DC: International Monetary Fund.

IMF. 2012e. Republic of Moldova: Letter of Intent, Memorandum of Economic and Financial Policies, and Technical Memorandum of Understanding (January 12). Washington, DC: International Monetary Fund.

IMF. 2012f. Solomon Islands: Letter of Intent, Memorandum of Economic and Financial Policies, and Technical Memorandum of Understanding (November 13). Washtington, DC: International Monetary Fund.

IMF. 2013a. "Greece: Ex Post Evaluation of Exceptional Access Under the 2010 Stand-by Arrangement.” IMF Country Report (13/156).

IMF. 2013b. "IMF-Supported Programs — Frequently Asked Questions.” International Monetary Fund. Retrieved May 19, 2015b (https://www.imf.org/external/np/exr/faq/progfaqs.htm).

IMF. 2013c. Portugal: Letter of Intent, Memorandum of Economic and Financial Policies, and Technical Memorandum of Understanding (October 24). Washington, DC: International Monetary Fund.

IMF. 2013d. "Social Safety Nets Key to Helping Poorest in Burkina Faso." IMF Survey. Retrieved May 16, 2015d (http://www.imf.org/external/pubs/ft/survey/so/2013/INT011613A.htm).

IMF. 2014a. Armenia: Letter of Intent, Memorandum of Economic and Financial Policies, and Technical Memorandum of Understanding (February 17). Washington, DC: International Monetary Fund.

IMF. 2014b. "Factsheet: the IMF's Advice on Labor Market Issues." International Monetary Fund. Retrieved April 21, 2015b (https://www.imf.org/external/np/exr/facts/labor.htm).

IMF. 2014c. "Fiscal Policy and Income Inequality." IMF Policy Paper January.

IMF. 2014d. Greece: Letter of Intent, Memorandum of Economic and Financial Policies, and Technical Memorandum of Understanding (May 14). Washington, DC: International 
Monetary Fund.

IMF. 2014e. Portugal: Letter of Intent, Memorandum of Economic and Financial Policies, and Technical Memorandum of Understanding (January 27). Washington, DC: International Monetary Fund.

IMF. 2014f. "The Case for Establishing a Comprehensive Social Protection System in Uganda." International Monetary Fund. Retrieved April 21, $2015 \mathrm{f}$ (http://www.imf.org/external/country/UGA/rr/2014/103014.pdf).

IMF. 2014g. "Transcript of the International Monetary and Financial Committee (IMFC) Press Briefing." International Monetary Fund. Retrieved April 21, 2015g (https://www.imf.org/external/np/tr/2014/tr041214b.htm).

IMF. 2014h. Tunisia: Letter of Intent, Memorandum of Economic and Financial Policies, and Technical Memorandum of Understanding (January 28). Washington, DC: International Monetary Fund.

IMF. 2014i. Ukraine: Letter of Intent, Memorandum of Economic and Financial Policies, and Technical Memorandum of Understanding (August 18). Washington, DC: International Monetary Fund.

IMF. 2015a. "Factsheet - IMF Conditionality." International Monetary Fund. Retrieved June 12, 2015a (https://www.imf.org/external/np/exr/facts/conditio.htm).

IMF. 2015b. "Factsheet: Protecting the Most Vulnerable Under IMF-Supported Programs." International Monetary Fund. Retrieved April 21, 2015b (https://www.imf.org/external/np/exr/facts/protect.htm).

ITUC. 2012. "Submission From ITUC/Global Unions to IMF's 2011 Review of Conditionality." International Trade Union Confederation. Retrieved April 22, 2015 (http://www.ituc-csi.org/submission-from-ituc-global-unions.html?lang=en).

ITUC. 2013. "Involvement of the International Monetary Fund in Labour Market Reforms in European Countries." ITUC Background Paper 1-28. Retrieved May 5, 2015 (http://www.ituc-csi.org/imf-involvement-in-labour-market).

Ivanova, A., W. Mayer, A. Mourmouras, and G. Anayiotos. 2001. "What Determines the Success or Failure of Fund-Supported Programs?." IMF Working Paper (November).

Kapur, D. 2005. "Conditionality and Its Alternatives." Pp. 31-58 in The IMF and the World Bank at sixty, edited by A. Buira. London: Anthem.

Kentikelenis, A. 2015. "Bailouts, Austerity and the Erosion of Health Coverage in Southern Europe and Ireland.” European Journal of Public Health 25(3):365-66.

Kentikelenis, A. et al. 2011. "Health Effects of Financial Crisis: Omens of a Greek Tragedy." 
The Lancet 378(9801):1457-58.

Kentikelenis, A., L. P. King, M. McKee, and D. Stuckler. 2014a. "The International Monetary Fund and the Ebola Outbreak." The Lancet Global Health 3(2):e69-e70.

Kentikelenis, A., M. Karanikolos, A. Reeves, M. McKee, and D. Stuckler. 2014b. "Greece's Health Crisis: From Austerity to Denialism.” The Lancet 383(9918):748-53.

Kentikelenis, A., T. H. Stubbs, and L. P. King. 2015. "Structural Adjustment and Public Spending on Health: Evidence From IMF Programs in Low-Income Countries.” Social Science \& Medicine 126:169-76.

Krasner, S. D. 1999. Sovereignty: Organized Hypocrisy. Princeton: Princeton University Press.

Kumar, N. and K. P. Gallagher. 2007. 'Relevance of 'Policy Space' for Development: Implications for Multilateral Trade Negotiations.” RIS Discussion Paper 120(March).

Leckow, R. 2002. "Conditionality in the International Monetary Fund.” International Monetary Fund. Retrieved April 22, 2015 (https://www.imf.org/external/np/leg/sem/2002/cdmfl/eng/leckow.pdf).

Lefrançois, F. 2010. The IMF, the Global Crisis \& Human Resources for Health: Still Constraining Policy Space. London: UK Consortium on AIDS \& International Development and Action for Global Health UK.

Lipson, M. 2007. "Peacekeeping: Organized Hypocrisy?." European Journal of International Relations 13(1):5-34.

Lissakers, K., I. Husain, and N. Woods. 2006. "Report of the External Evaluation of the Independent Evaluation Office.” IMF Independent Evaluation Office. Retrieved June 16, 2015 (http://www.imf-ieo.org/ieo/files/evaluationofieo/032906.pdf).

Lloyd, V. and R. Weissman. 2002. "How International Monetary Fund and World Bank Policies Undermine Labor Power and Rights." International Journal of Health Services 32(3):433-42.

Marphatia, A. A. 2009. "The Adverse Effects of International Monetary Fund Programs on the Health and Education Workforce.” International Journal of Health Services 40(1):165-78.

Marphatia, A. A., R. Moussie, A.-M. Ainger, and D. Archer. 2007. Confronting the Contradictions: the IMF, Wage Bill Caps and the Case for Teachers. London: ActionAid International.

Martijn, J. K. and S. Tareq. 2007. "IMF Moves to Clarify Aid Role.” IMF Survey. Retrieved May 16, 2015 (http://www.imf.org/external/pubs/ft/survey/so/2007/NEW0720B.htm).

Mayer, J. 2008. "Policy Space: What, for What, and Where?." UNCTAD Discussion Papers 191(October). 
McColl, K. 2008. "Fighting the Brain Drain.” BMJ 337:a1496.

McCoy, D. et al. 2000. "Salaries and Incomes of Health Workers in Sub-Saharan Africa." The Lancet 371(9613):675-81.

McDonald, C. 2007. “A Response to ActionAid International." International Monetary Fund. Retrieved May 21, 2015 (https://www.imf.org/external/np/vc/2007/051707.htm).

Meltzer, A. H. 2000. Report of the International Financial Institution Advisory Commission. Washington, DC: United States Government Printing Office.

Meyer, J. W. and B. Rowan. 1977. "Institutionalized Organizations: Formal Structure as Myth and Ceremony." American Journal of Sociology 83(2):340-63.

Momani, B. and E. Helleiner. 2007. "Slipping Into Obscurity? Crisis and Reform at the IMF." Centre for International Governance Innovation Working Paper 16.

Muchhala, B. 2011. "The IMF's Financial Crisis Loans: No Change in Conditionalities." Third World Network Global Economy Series (30).

Mundy, K. and F. Menashy. 2014. "The World Bank and Private Provision of Schooling: a Look Through the Lens of Sociological Theories of Organizational Hypocrisy." Comparative Education Review 58(3):401-27. Retrieved (http://www.jstor.org/stable/10.1086/676329).

Nelson, S. C. 2014a. "International Financial Institutions and Market Liberalization in the Developing World." in The Oxford Handbook of the Politics of International Development, edited by N. van de Walle and C. Lancaster. Oxford: Oxford University Press.

Nelson, S. C. 2014b. "The International Monetary Fund's Evolving Role in Global Economic Governance." Pp. 156-70 in Handbook of Global Economic Governance, edited by M. Moschela and C. Weaver. Milton Park: Routledge.

Neumayer, E. and L. Spess. 2005. "Do Bilateral Investment Treaties Increase Foreign Direct Investment to Developing Countries?.” World Development 33(10):1567-85.

Nowzad, B. 1981. "The IMF and Its Critics.” Princeton Essays in International Finance 146(December).

Oberdabernig, D. A. 2013. "Revisiting the Effects of IMF Programs on Poverty and Inequality." World Development 46(C):113-42.

Ortiz, I., J. Chai, and M. Cummins. 2011. "Austerity Measures Threaten Children and Poor Households: Recent Evidence in Public Expenditures From 128 Developing Countries." UNICEF Social and Economic Policy Working Paper (September).

Ostry, J. D. et al. 2010. "Capital Inflows: the Role of Controls.” IMF Staff Position Note 
(SPN/10/04).

Ostry, J. D., A. Berg, and C. G. Tsangarides. 2014. "Redistribution, Inequality, and Growth." IMF Staff Discussion Note (SDN/14/02).

Payer, C. 1974. The Debt Trap: the IMF and the Third World. New York: Monthly Review Press.

Pfeffer, J. and G. R. Salancik. 1978. The External Control of Organizations: a Resource Dependence Perspective. New York: Harper \& Row.

Pisani-Ferry, J., A. Sapir, and G. Wolff. 2013. "EU-IMF Assistance to Euro-Area Countries: an Early Assessment." Bruegel Blueprint Series XIX.

Polak, J. J. 1991. "The Changing Nature of IMF Conditionality." Princeton Essays in International Finance 184.

Powell, W. W. and P. J. DiMaggio, eds. 1991. The New Institutionalism in Organizational Analysis. Chicago: University of Chicago Press.

Przeworski, A. and J. R. Vreeland. 2000. "The Effect of IMF Programs on Economic Growth." Journal of Development Economics 62:385-421.

Radelet, S. and J. D. Sachs. 1998. "The East Asian Financial Crisis: Diagnosis, Remedies, Prospects." Brookings Papers on Economic Activity 1998(1):1-90.

Reuters. 2010. "Romania Assembly Approves IMF-Backed Pension Reform.”

Reuters. 2014. "IMF Loan Conditions Grow Despite Vows to Limit Them: Study." Retrieved May 3, 2015 (http://www.reuters.com/article/2014/04/02/us-imf-conditionsidUSBREA311SZ20140402).

Rickard, S. J. and T. L. Caraway. 2014. "The International Politics of Austerity: the Puzzling Case of Public Sector Reforms." Presentation at the "Political Economy of International Organizations Annual Conference" (16 January). Retrieved September 4, 2014 (http://www.cidcm.umd.edu/workshop/papers/Rickard_and_Caraway.pdf).

Roaf, J. 2009. "IMF-Supported Programs in Crisis: Countercyclical, Not Procyclical!." CEPR. Retrieved May 3, 2015 (http://www.cepr.net/documents/presentations/imf-roaf-200910.ppt).

Rodrik, D. 2002. “After Neoliberalism, What?.” New Rules for Global Finance. Retrieved April 23, 2015 (http://www.new-rules.org/storage/documents/afterneolib/rodrik.pdf).

Rowden, R. 2008. "Blocking Progress: the IMF and HIV/AIDS." Global Social Policy $8(1): 19-24$.

Rowden, R. 2009. The Deadly Ideas of Neoliberalism: How the IMF Has Undermined Public 
Health and the Fight Against AIDS. London: Zed Books.

Scott, W. R. 1995. Institutions and Organizations. Thousand Oaks: Sage Publications.

Seabrooke, L. 2010. "Bitter Pills to Swallow: Legitimacy Gaps and Social Recognition of the IMF Tax Policy Norm in East Asia.” Pp. 137-60 in Owning development: creating policy norms in the IMF and the World Bank, edited by S. Park and A. Vetterlein. Cambridge: Cambridge University Press.

Serra, N. and J. E. Stiglitz, eds. 2008. The Washington Consensus Reconsidered: Towards a New Global Governance. Oxford: Oxford University Press.

Shadlen, K. 2005. "Policy Space for Development in the WTO and Beyond: the Case of Intellectual Property Rights.” GDAE Working Paper 05-06.

Simon, H. A. 1997. Administrative Behavior. 4 ed. New York: Free Press.

Spraos, J. 1986. "IMF Conditionality: Ineffectual, Misguided, Mistargeted.” Princeton Essays in International Finance 166(December).

Stewart, F. 1991. “The Many Faces of Adjustment.” World Development 19(12):1847-64.

Stewart, F. and M. Wang. 2003. "Do PRSPs Empower Poor Countries and Disempower the World Bank, or Is It the Other Way Round?" QEH Working Paper Series 108.

Stiglitz, J. E. 2002. Globalization and Its Discontents. New York: W. W. Norton \& Company.

Stone, R. W. 2008. “The Scope of IMF Conditionality.” International Organization 62(4):589620.

Stubbs, T. H., A. Kentikelenis, and L. P. King. 2016. "Catalyzing Aid? the IMF and Donor Behavior in Aid Allocation." World Development 78:511-28.

Stuckler, D. and S. Basu. 2009. "The International Monetary Fund's Effects on Global Health: Before and After the 2008 Financial Crisis." International Journal of Health Services 39(4):771-81.

Stuckler, D. et al. 2010. "An Evaluation of the International Monetary Fund's Claims About Public Health.” International Journal of Health Services 40(2):327-32.

Summers, L. and L. H. Pritchett. 1993. "The Structural-Adjustment Debate." The American Economic Review 83(2):383-89.

The Guardian. 2015. "Ebola Outbreak: We Simply Could Not Cope, Admits World Health Organisation.” Retrieved June 12, 2015 (http://web.archive.org/web/20150420043704/http://www.theguardian.com/world/2015/ap r/20/ebola-outbreak-we-simply-could-not-cope-admits-world-health-organisation). 
Toye, J. 1994. "Structural Adjustment: Context, Assumptions, Origin and Diversity." Pp. 1835 in Structural adjustment and beyond in Sub-Saharan Africa: research and policy issues, edited by R. V. D. Hoeven and F. V. D. Kraaij. London: Heinemann.

UN. 2012. "Global Health and Foreign Policy." United Nations General Assembly (Sixtyseventh session; agenda item 123). Retrieved June 23, 2015 (http://www.un.org/ga/search/view_doc.asp?symbol=A/67/L.36).

UNDP. 1990. Human Development Report 1990. New York: United Nations Development Programme.

van der Hoeven, R. and F. Stewart. 1993. "Social Development During Periods of Structural Adjustment in Latin America." ILO Occasional Paper 18:1-32.

Van Waeyenberge, E., H. Bargawi, and T. McKinley. 2010. "Standing in the Way of Development? a Critical Survey of the IMF's Crisis Response in Low Income Countries." Eurodad \& Third World Network report. Retrieved April 22, 2015 (http://eurodad.org/uploadedfiles/whats_new/reports/standing\%20in\%20the\%20way\%20of \%20development(1).pdf).

Verhoeven, M. and A. Segura. 2007. "IMF Trims Use of Wage Bill Ceilings." IMF Survey. Retrieved May 16, 2015 (http://www.imf.org/external/pubs/ft/survey/so/2007/POL095A.htm).

Vetterlein, A. 2010. "Lacking Ownership: the IMF and Its Engagement with Social Development as a Policy Norm.” Pp. 93-112 in Owning development: creating policy norms in the IMF and the World Bank, edited by S. Park and A. Vetterlein. Cambridge: Cambridge University Press.

Vreeland, J. R. 2003. The IMF and Economic Development. Cambridge: Cambridge University Press.

Wade, R. H. 1996. "Japan, the World Bank, and the Art of Paradigm Maintenance: the East Asian Miracle in Political Perspective." New Left Review I/217:3-36.

Wade, R. H. 2003. "What Strategies Are Viable for Developing Countries Today? the World Trade Organization and the Shrinking of 'Development Space'." Review of International Political Economy 10(4):621-44.

Weaver, C. 2008. Hypocrisy Trap: the World Bank and the Poverty of Reform. Princeton: Princeton University Press.

Weisbrot, M., R. Ray, J. Johnston, J. A. Cordero, and J. A. Montecino. 2009. IMF-Supported Macroeconomic Policies and the World Recession: a Look at Forty-One Borrowing Countries. Washington DC: Center for Economic and Policy Research.

WHO. 2013. World Health Report 2013: Research for Universal Health Coverage. Geneva: 
World Health Organization.

WHO. 2014. Health Systems Governance for Universal Health Coverage. Geneva: World Health Organization.

WHO. 2015. "WHO Leadership Statement on the Ebola Response and WHO Reforms." World Health Organization. Retrieved June 12, 2015 (http://www.who.int/csr/disease/ebola/jointstatement-ebola/en/).

Williamson, J. 1990. "What Washington Means by Policy Reform." in Latin American Adjustment: How Much Has Happened?, edited by J. Williamson. Washington DC: Peterson Institute for International Economics.

Williamson, J., ed. 1983. IMF Conditionality. Washington: Institute for International Economics.

Wolf, M. 2011. "Iceland's Recovery_Lessons and Challenges." IMF. Retrieved April 27, 2015 (http://www.imf.org/external/np/seminars/eng/2011/isl/index.htm).

Woods, N. 2006. The Globalizers: the IMF, the World Bank, and Their Borrowers. Ithaca: Cornell University Press. 


\section{Appendix I. Measuring IMF Conditionality}

To capture different dimensions of conditionality, we extracted relevant information from loan agreements. When requesting a loan from the IMF, countries send a letter to its management setting out the loan specifics (e.g. amount and duration), main objectives, and associated conditionality. These documents - drafted by country policymakers in collaboration with IMF staff-are known as Letters of Intent with attached Memoranda of Economic and Financial Policies, and are reviewed and updated in regular intervals. For example, a program that is reviewed five times over its duration is linked to six Letters of Intent and Memoranda of Economic and Financial Policies: one for the original approval and then one for each review. This set of documents forms our data, and we extracted the raw text of all conditions, including the number of times conditions were applicable per year (relevant for quantitative conditions which commonly apply on a quarterly basis). Replication of coding was performed in various stages to ensure inter-coder reliability. Where uncertainties arose, they were discussed and resolved by consensus. In all cases requiring a coding decision, we opted for the most cautious approach (i.e. one that would understate conditionality). Missing documents were not a major issue: only 58 documents were missing, compared to 1,995 documents collected and coded. Nonetheless, these documents - still classified by the IMF-primarily relate to some of the most controversial loans: Argentina (1984-88, 1997, 2003), Brazil (1988, 1991, 1998-2000), Korea (1997-99), Philippines (1984-85, 1998), Thailand (1997-2000), and Turkey (19992003).

After the raw text of all conditions was extracted, the second stage of the coding process entailed classifying them into mutually exclusive policy areas (summarized in Table 2 above), building on practices adopted by the IMF's Independent Evaluation Office (IEO 2007b), the IMF Monitoring of Fund Arrangements database and academic research, and taking into account the potential for miscoding. Since the classification of conditions presented a larger such potential, all of it was conducted independently by two researchers and then compared. Discrepancies were discussed and resolved by consensus. Occasionally, conditions did not neatly fit in a policy area. Faced with this obstacle, we had three options available to us: splitting the condition, classifying the condition under the policy area we considered most appropriate, or merging policy areas to make them more inclusive. We resorted to a combination of these approaches. First, we yielded approximately 250 additional conditions by splitting the condition text; this occurred only in cases where their content was in substantively different policy areas. For example, the text for a condition in Jordan's 1999 program stipulated the 'reduction in the maximum import tariff rate to 35 percent, together with an increase in the GST [general sales tax] rate to at least 12 percent' (IMF 1999). This was subsequently split into two conditions - one on trade issues and another on tax policy. Second, we classified conditions under the 'main' policy area in the majority of instances of ambiguity. Common examples are budget-related conditions, like 'submit budget law to Parliament for approval, including limits on government wage bill.' In this instance, despite containing measures directly affecting labour, we classified this condition under the fiscal issues policy area. Splitting such conditions would have led to a substantial inflation of conditionality; our approach is more cautious. Third, where ambiguous conditions contained reforms in 'neighbouring' policy areas, we opted to merge entire areas. The main examples of such 
merging are the categories 'financial sector, monetary policy, and Central Bank issues' and 'fiscal issues, revenues and tax.'

As noted above, the IMF has its own conditionality database, known as Monitoring of Fund Arrangements (MONA). This database is compiled by the IMF's Policy Development and Review department (now known as Strategy, Policy, and Review department), and-over the years - has been criticised (Arpac et al. 2008; IEO 2007a). We sought to produce a resource independent of the IMF, and each condition is fully referenced to its source document to enhance transparency and enable replication. 
Table 1. Descriptive statistics on conditionality

\begin{tabular}{|c|c|c|c|c|}
\hline & Mean & Median & $\begin{array}{l}\text { Progr- } \\
\text { ammes }\end{array}$ & Highest conditionality in... \\
\hline 1985 & 20.9 & 23 & 36 & Jamaica (42 conditions), Argentina (36), Ghana (32) \\
\hline 1986 & 20.9 & 17 & 43 & Morocco (65), Zambia (63), Congo, Dem. Rep. (40) \\
\hline 1987 & 27.3 & 28 & 35 & Tanzania (49), Niger (42), Gabon, Senegal \& Tunisia (40) \\
\hline 1988 & 25.3 & 24 & 46 & Tanzania (57), Togo (56), Tunisia (49) \\
\hline 1989 & 28.8 & 30 & 50 & Pakistan (87), Nepal (56), Tunisia (52) \\
\hline 1990 & 26.7 & 25.5 & 50 & Pakistan (61), Tanzania (59), Gabon (54) \\
\hline 1991 & 26.9 & 25 & 53 & Tunisia (52), Rwanda \& Senegal (46) \\
\hline 1992 & 29.7 & 29 & 54 & India (62), Gabon (56), Pakistan (54) \\
\hline 1993 & 28.4 & 28 & 48 & Mauritania (73), Egypt (56), Burkina Faso (53) \\
\hline 1994 & 36.5 & 36.5 & 60 & Mauritania (76), Kyrgyz Republic (70), Albania (66) \\
\hline 1995 & 36.3 & 37 & 67 & Mauritania (88), Ukraine (78), Armenia (72) \\
\hline 1996 & 43.9 & 42.5 & 68 & Azerbaijan (93), Russian Federation (87), Georgia (70) \\
\hline 1997 & 42.9 & 42 & 60 & Kazakhstan (99), Bulgaria (89), Azerbaijan (88) \\
\hline 1998 & 43.2 & 43.5 & 60 & Russian Federation (143), Ukraine (103), Indonesia (77) \\
\hline 1999 & 44.3 & 41 & 62 & Ukraine (148), Bulgaria (99), Moldova (89) \\
\hline 2000 & 40.8 & 42.5 & 64 & Kyrgyz Republic (97), Bulgaria (87), Romania (79) \\
\hline 2001 & 41.8 & 40 & 66 & Pakistan (105), Armenia (72), Rwanda (72) \\
\hline 2002 & 42.9 & 39.5 & 58 & Romania (114), Pakistan (98), Turkey (86) \\
\hline 2003 & 45.3 & 45 & 57 & Romania (114), Pakistan (87), Macedonia, FYR (80) \\
\hline 2004 & 43.5 & 47 & 57 & Romania (126), Serbia (87), Nicaragua (74) \\
\hline 2005 & 44.5 & 43 & 47 & Serbia (122), Romania (100), Senegal (83) \\
\hline 2006 & 39.7 & 41 & 43 & Cameroon (79), Congo, Rep. (65), FYR Macedonia (65) \\
\hline 2007 & 40.4 & 40 & 37 & $\begin{array}{l}\text { Cameroon (84), Dominican Rep. (77), FYR Macedonia } \\
\text { (67) }\end{array}$ \\
\hline 2008 & 30.4 & 33 & 46 & Cameroon (75), Moldova (62), Haiti (60) \\
\hline 2009 & 31.8 & 33 & 53 & $\begin{array}{l}\text { Cote d'Ivoire (70), Afghanistan (53), Central African Rep. } \\
\text { (51) }\end{array}$ \\
\hline 2010 & 32.9 & 34 & 60 & Cote d'Ivoire \& Ghana (60), Tajikistan (58) \\
\hline 2011 & 31.6 & 32 & 50 & Haiti (60), Tajikistan (58), Ghana (54) \\
\hline 2012 & 32.5 & 35 & 45 & Greece (62), Afghanistan (60), Cote d'Ivoire (59) \\
\hline 2013 & 33.7 & 34.5 & 40 & Bosnia \& Herzeg. (85), Bangladesh (69), Cote d'Ivoire (68) \\
\hline 2014 & 38.7 & 44 & 35 & Bosnia \& Herzeg. (92), Ukraine (64), Jamaica (63) \\
\hline
\end{tabular}

$\begin{array}{llll}\text { Total } & 35.8 & 34.0 & \text { Romania }(1,231) \text {, Pakistan }(1,129), \text { Mauritania }(1,058)\end{array}$

Source: Authors' database. 
Table 2. Categorization of Policy Areas

\begin{tabular}{|c|c|c|}
\hline & Policy Area Description & $\begin{array}{l}\text { Number of } \\
\text { conditions }\end{array}$ \\
\hline \multirow{4}{*}{ 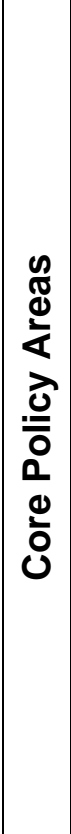 } & $\begin{array}{l}\text { External debt issues } \\
\text { Debt management and external arrears. }\end{array}$ & 15,407 \\
\hline & $\begin{array}{l}\text { Financial sector, monetary policy, and Central Bank issues } \\
\text { Financial institution regulation, financial SOE privatization, treasury } \\
\text { bills, interest rates, Central Bank regulation, money supply, and } \\
\text { domestic credit. }\end{array}$ & 13,948 \\
\hline & $\begin{array}{l}\text { Fiscal issues, revenues and taxation } \\
\text { Expenditure administration, fiscal transparency, audits, budget } \\
\text { preparation, domestic arrears, and fiscal balance, customs } \\
\text { administration, tax policy, tax administration, and audits of private } \\
\text { enterprises. }\end{array}$ & 13,756 \\
\hline & $\begin{array}{l}\text { External sector (trade and exchange system) } \\
\text { Foreign reserves, trade liberalization, exchange rate policy, capital } \\
\text { account liberalization, and foreign direct investment. }\end{array}$ & 4,885 \\
\hline \multirow{5}{*}{ 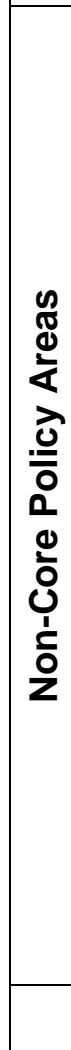 } & $\begin{array}{l}\text { State-owned enterprise privatization, reform and pricing } \\
\text { Non-financial SOE privatization (incl. liquidation and bankruptcy } \\
\text { proceedings), SOE restructuring, subsidies, price liberalization, audits, } \\
\text { marketing boards, and corporatization and rationalization. }\end{array}$ & 3,303 \\
\hline & $\begin{array}{l}\text { Labour issues (public and private sector) } \\
\text { Wage and employment limits, pensions, and social security } \\
\text { institutions. }\end{array}$ & 1,987 \\
\hline & $\begin{array}{l}\text { Institutional reforms } \\
\text { Judicial system reforms, anti-corruption measures, competition } \\
\text { enhancement, private sector development, devolution, sectoral } \\
\text { policies, social policies (excl. poverty reduction policies), price } \\
\text { increases for food, water, public transport, or other basic needs goods, } \\
\text { land registries, granting of property rights, environmental regulations } \\
\text { and access to commons. }\end{array}$ & 1,357 \\
\hline & $\begin{array}{l}\text { Poverty reduction policies } \\
\text { Poverty Reduction Strategy Paper development, increases in social } \\
\text { sector spending, and implementation of social safety nets. }\end{array}$ & 822 \\
\hline & Total Number of Conditions & 55,465 \\
\hline
\end{tabular}

Note: We also collected the conditions from so-called low conditionality facilities: First Credit Tranche (FCT), Emergency Assistance for Post-Conflict Situations (EAPC) and Natural Disasters (EAND), Systemic Transformation Facility (STF), Exogenous Shock Facility - Rapid Access Credit (ESF-RAC), and Rapid Credit Facility (RCF). These yielded another 1,129 conditions not included here.

Source: Authors' database. 
Table 3. Pro-poor spending conditions in Sub-Saharan Africa since 1995

\begin{tabular}{|l|c|c|c|}
\hline & Total & $\begin{array}{c}\text { Of which } \\
\text { implementation data } \\
\text { available for... }\end{array}$ & $\begin{array}{c}\text { Of which } \\
\text { implemented... }\end{array}$ \\
\hline Western Africa & 283 & 210 & 97 \\
\hline Central Africa & 55 & 38 & 23 \\
\hline Eastern \& Southern Africa & 137 & 114 & 64 \\
\hline TOTAL & 475 & 362 & 184 \\
\hline
\end{tabular}

Note: Number of targets (spending floors) reported in IMF lending programmes (often applicable on a bi-annual or quarterly basis). Spending floors are set for 'priority expenditures' that include health, education, and other social sectors.

Source: Various IMF lending arrangements retrieved from the IMF Archives. 
Table 4. Implementation of selected conditions in West Africa since 2010

\begin{tabular}{|l|c|c|c|}
\hline Country Name & Year & Social spending floors & $\begin{array}{c}\text { Budget balance } \\
\text { conditions (or similar) }\end{array}$ \\
\hline Angola & 2010 & $0 \%[4 / 3 / 0]$ & $100 \%[4 / 3 / 3]$ \\
\hline Benin & 2011 & $0 \%[4 / 4 / 0]$ & $100 \%[4 / 4 / 4]$ \\
\hline Burkina Faso & 2011 & $0 \%[4 / 2 / 0]$ & $100 \%[4 / 2 / 2]$ \\
\hline Burkina Faso & 2013 & $0 \%[4 / 1 / 0]$ & $100 \%[3 / 3 / 3]$ \\
\hline Chad & 2014 & $0 \%[2 / 1 / 0]$ & $0 \%[2 / 1 / 0]$ \\
\hline Cote d'Ivoire & 2010 & $0 \%[4 / 2 / 0]$ & $100 \%[4 / 1 / 1]$ \\
\hline Djibouti & 2010 & $0 \%[1 / 1 / 0]$ & $100 \%[1 / 1 / 1]$ \\
\hline Djibouti & 2011 & $25 \%[4 / 4 / 1]$ & $33.3 \%[4 / 3 / 1]$ \\
\hline Ghana & 2012 & $0 \%[2 / 1 / 0]$ & $0 \%[2 / 1 / 0]$ \\
\hline Guinea & 2012 & $25 \%[4 / 4 / 1]$ & $100 \%[4 / 4 / 4]$ \\
\hline Guinea & 2013 & $0 \%[4 / 4 / 0]$ & $100 \%[4 / 4 / 4]$ \\
\hline Guinea-Bissau & 2010 & $25 \%[4 / 4 / 1]$ & $100 \%[4 / 4 / 4]$ \\
\hline Mali & 2010 & $0 \%[3 / 3 / 0]$ & $100 \%[4 / 4 / 4]$ \\
\hline Mauritania & 2010 & $0 \%[4 / 4 / 0]$ & $100 \%[4 / 4 / 4]$ \\
\hline Niger & 2013 & $0 \%[4 / 4 / 0]$ & $75 \%[4 / 4 / 3]$ \\
\hline Niger & 2014 & $0 \%[4 / 3 / 0]$ & $0 \%[4 / 3 / 0]$ \\
\hline Sierra Leone & 2013 & $0 \%[2 / 2 / 0]$ & $50 \%[2 / 2 / 1]$ \\
\hline Togo & 2010 & $0 \%[2 / 2 / 0]$ & $100 \%[3 / 3 / 3]$ \\
\hline
\end{tabular}

Note: Implementation rate is defined as the share of implemented conditions relative to conditions for which we found implementation data. Figures in brackets report - in sequence - the total number of conditions we identified, those for which we found implementation data, and those that were implemented. Multiple occurrences of conditions denote quarterly or biannual basis. Liberia (2014) and Malawi (2012-14) are excluded from the table because no explicit budget balance conditionality was attached to lending programmes.

Source: Various IMF lending arrangements retrieved from the IMF Archives. 
Figure 1. Total conditions, 1985-2014

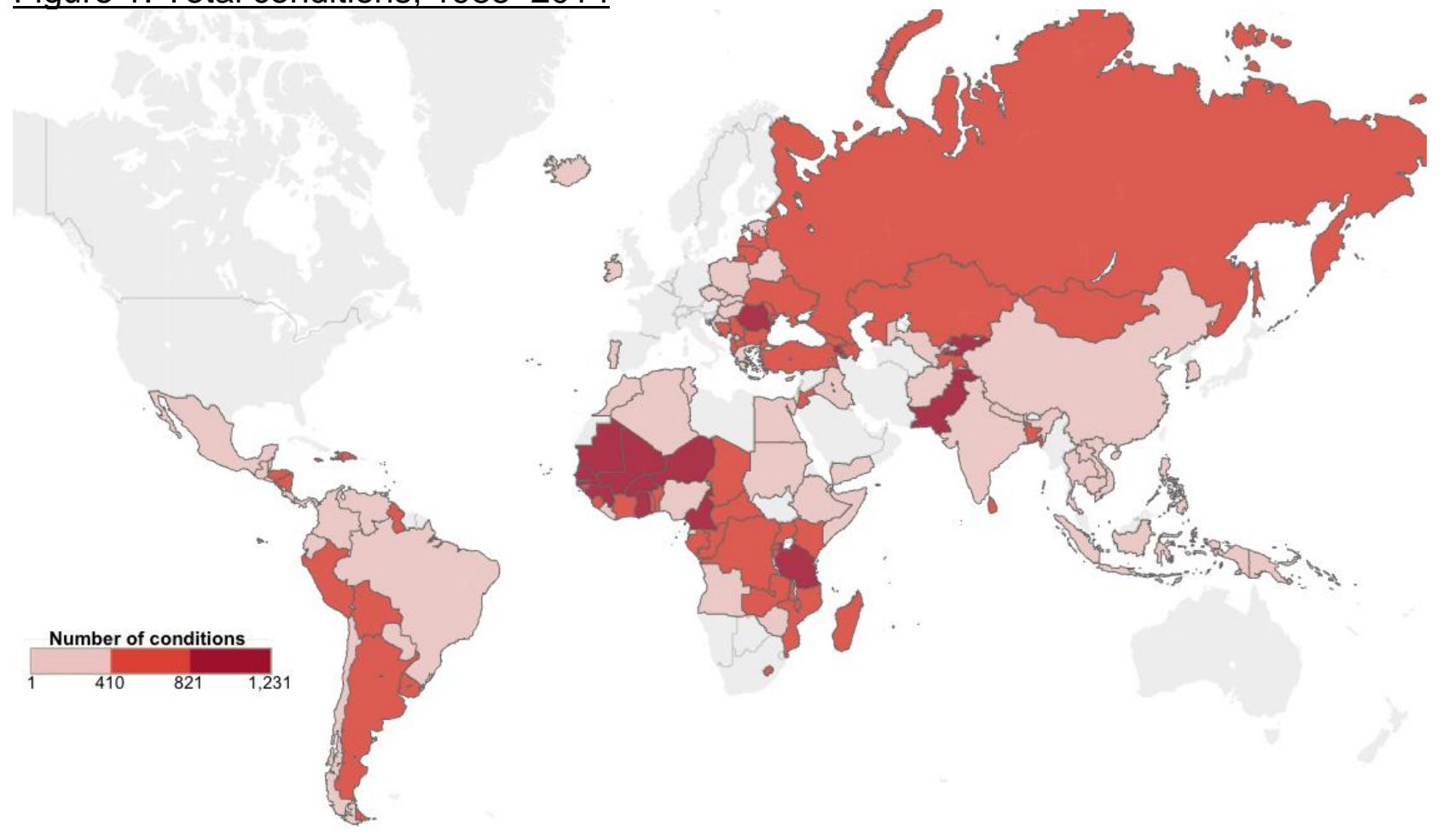

Source: Authors' database. 
Figure 2. Mean of structural conditions in IMF programmes

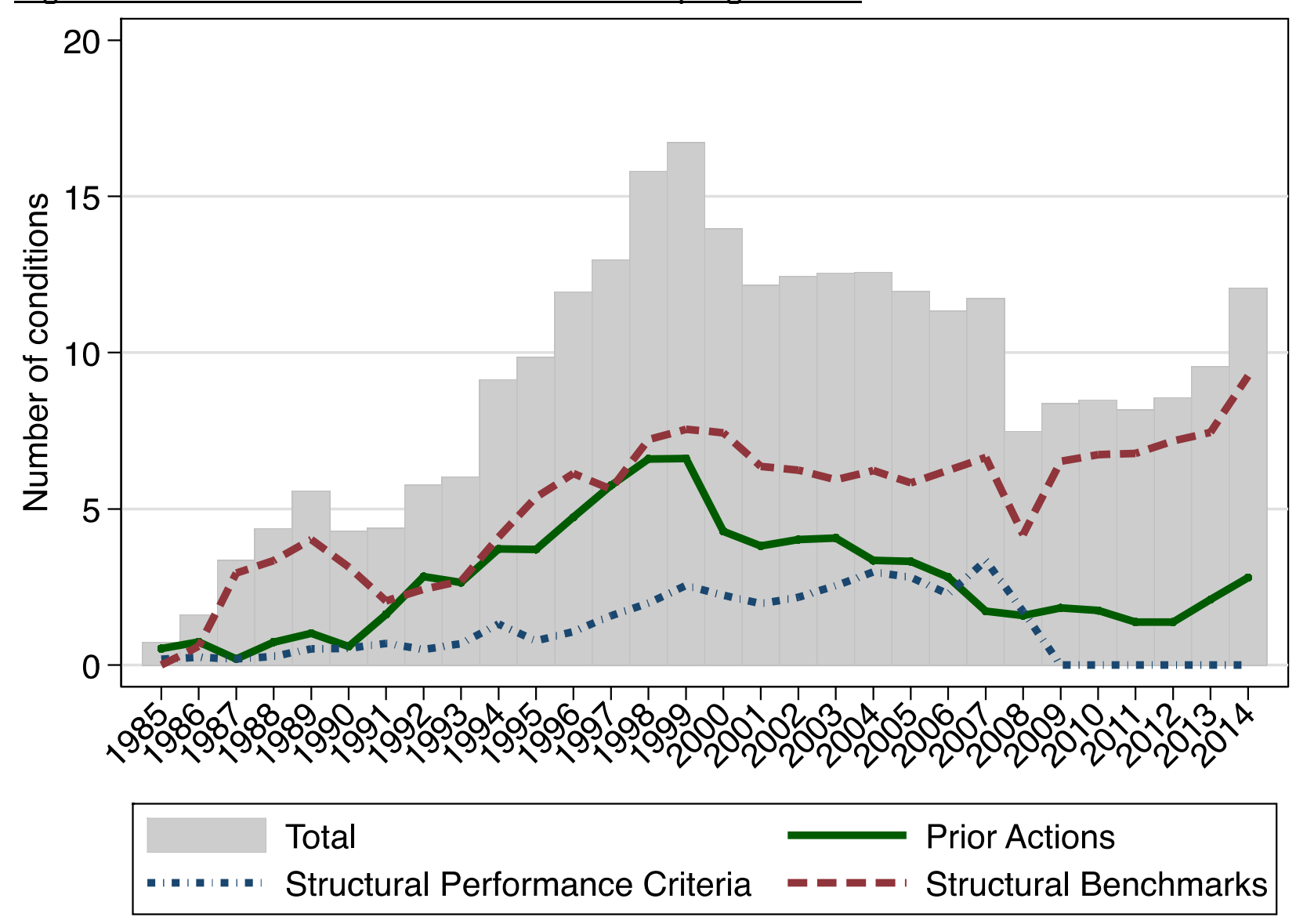

Source: Authors' database. 
Figure 3. Policy areas under reform in IMF programmes

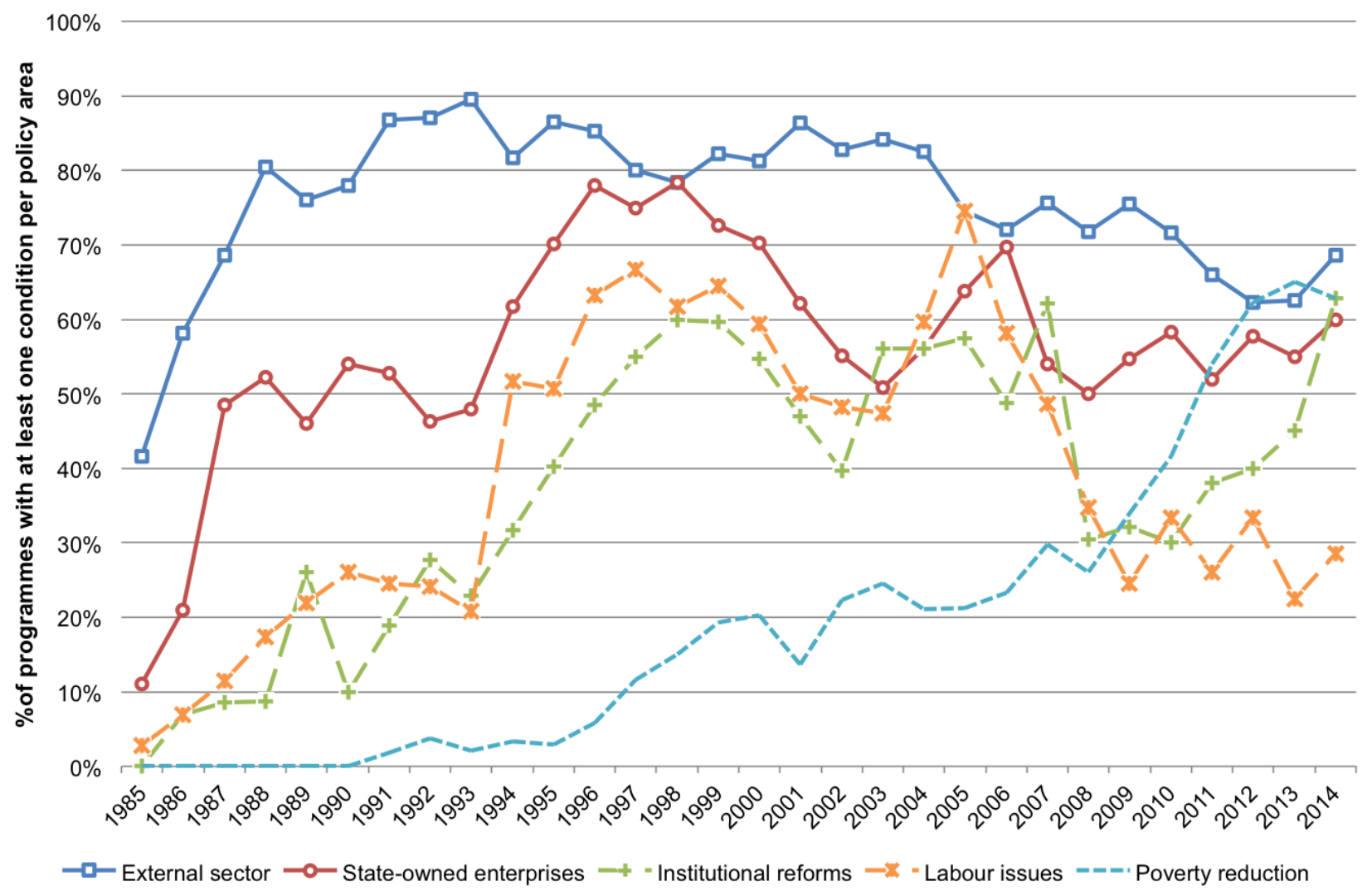

Source: Authors' database. 